Working Paper/Document de travail 2011-14

\title{
Real-Financial Linkages in the Canadian Economy: An Input-Output Approach
}

by Danny Leung and Oana Secrieru 
Bank of Canada Working Paper 2011-14

May 2011

\title{
Real-Financial Linkages in the Canadian Economy: An Input-Output Approach
}

by

\author{
Danny Leung ${ }^{1}$ and Oana Secrieru ${ }^{2}$ \\ ${ }^{1}$ Statistics Canada \\ Ottawa, Ontario, Canada K1A 0T6 \\ Danny.Leung@statcan.gc.ca \\ ${ }^{2}$ Canadian Economic Analysis Department \\ Bank of Canada \\ Ottawa, Ontario, Canada K1A 0G9 \\ osecrieru@bankofcanada.ca
}

Bank of Canada working papers are theoretical or empirical works-in-progress on subjects in economics and finance. The views expressed in this paper are those of the authors.

No responsibility for them should be attributed to Statistics Canada or the Bank of Canada. 


\section{Acknowledgements}

The authors would like to thank John Baldwin, Pierre Duguay, Bob Fay, Larry St. Louis, Pierre Mohnen, Malik Shukayev, and Karen Wilson for their comments on earlier drafts of the paper. The paper also benefited from conversations with Ziad Ghanmen, Luke Rispoli and Yusuf Siddiqi. 


\begin{abstract}
The purpose of this paper is twofold. First, we provide a detailed social accounting matrix (SAM), which incorporates the income and financial flows into the standard input-output matrix, for the Canadian economy for 2004. Second, we use the SAM to assess the strength of the real-financial linkages by calculating and comparing real SAM multipliers and financial social accounting matrix (FSAM) multipliers. For FSAM multipliers, financial flows are endogenous, whereas for real SAM multipliers they are not. Our results show that taking into account financial flows increases the impact of a final demand shock on Canadian output. Financial flows also play an important role in determining the cumulative effect of an income shock or the availability of investment funds. Between 2008 and the first half of 2009, financial institutions shifted their investments towards government bonds, short-term paper, and foreign investments. This shift together with the fact that non-financial institutions were unwilling or unable to increase their financial liabilities, led to estimated declines in all GDP multipliers between 2008 and the first half of 2009 (2009H1). The main advantage of using the extended input-output impact analysis is that it provides a simple framework, with very few assumptions, which allows the assessment of the strength of real-financial linkages by means of multipliers. However, our methodology is subject to the Lucas critique, that as shocks shift prices, agents cannot adjust. Such a framework is, nevertheless, appropriate in short-term impact analysis such as ours.
\end{abstract}

JEL classification: C67, D57

Bank classification: Economic models; Financial markets; Sectoral balance sheet

\title{
Résumé
}

Les auteurs poursuivent un double objectif. D’abord, représenter l'économie canadienne de 2004 sous la forme d'une matrice de comptabilité sociale détaillée (matrice SAM) intégrant à la matrice entrées-sorties usuelle les flux de revenus et les flux financiers. Ensuite, se servir de la matrice SAM pour mesurer la force des relations entre l'économie réelle et le secteur financier, en calculant et comparant des multiplicateurs pour l'économie réelle et la sphère financière. Les flux financiers sont présumés endogènes dans les multiplicateurs de la sphère financière et exogènes dans les multiplicateurs de l'économie réelle. Les résultats obtenus montrent que la prise en compte des flux financiers intensifie l'incidence du choc de demande finale sur la production canadienne. Ces flux jouent aussi un rôle important quand il s'agit de déterminer l'effet cumulatif d'un choc de revenu ou la disponibilité de fonds d'investissement. De 2008 à la première moitié de 2009, les institutions financières ont orienté leurs investissements vers les obligations d'État, le papier à court terme et les placements étrangers. Ce changement de cap, allié au fait que les institutions non financières évitaient d'accroître leurs passifs financiers ou étaient incapables de les augmenter, a entraîné durant cette période un recul de la valeur estimée de tous les multiplicateurs du PIB. Le grand avantage d'une analyse 
entrées-sorties élargie est qu'elle fournit un cadre simple, au nombre d’hypothèses limité, permettant d'évaluer l'ampleur des interdépendances de l'économie réelle et du secteur financier à partir de multiplicateurs. Même si, du fait que les agents ne peuvent s'adapter aux mouvements de prix induits par les chocs, la méthode des auteurs est la cible de la critique de Lucas, le modèle proposé garde sa pertinence pour le genre d'étude d'impact de court terme présentée.

Classification JEL : C67, D57

Classification de la Banque : Modèles économiques; Marchés financiers; Bilan sectoriel 


\section{$1 \quad$ Introduction}

The recent financial crisis has shown that financial markets and intermediaries have significant and important effects on the real economy. The objective of this study is to provide a framework that captures real-financial linkages and to assess the strength of these linkages in the Canadian economy. Our framework of choice is an input-output model that takes into account the financial flows occurring in the economy.

In recent years, there has been an increased interest in input-output analysis and its multiple applications, in particular to interregional and regional analysis, productivity analysis, ${ }^{1}$ Computable General Equilibrium modeling, and environmental policies. ${ }^{2}$ Input-output tables have also been used to look at the net trade exposure and, more recently, the restructuring going on in the North American auto industry. ${ }^{3}$

Input-output models are commonly used to calculate multipliers that track the effect of an exogenous increase in the final demand for one industry's output on other industries, showing the linkages between the industries. For example, an increase in U.S. demand for Canadian manufactures would directly increase production in manufacturing and also stimulate growth in the industries that provide inputs to manufacturing. The fact that these other industries may themselves use inputs produced by the Canadian manufacturing industry leads to successive rounds of increased production or to a multiplier effect.

Input-output models can be extended to show how the increase in production from a final demand shock also boosts the incomes of households and corporations, and how this increase in income leads to further consumption and investment (and yet more production) or savings. It can also be extended to capture the workings of the financial system, allowing households and corporations to borrow from the pool of savings in the economy in order to finance even more investment spending. This extended framework is called a social accounting matrix (SAM). Since the SAM framework captures the linkage between production and income, and the workings of the financial system, it also expands the type of multipliers that can be analyzed. In addition to exogenous increases in final demand, one can also consider an exogenous increase to household income or an exogenous increase to the investment funds of financial institutions, for example.

In this paper, we consider three types of multipliers: Input-output, real SAM and financial social accounting matrix (FSAM) multipliers. These multipliers can all be calculated using data from a SAM. What distinguish these multipliers from each other are the linkages that are assumed to be exogenous. In the case of input-output multipliers, the links between production, income generation, and uses of income are assumed to be exogenous, as are the workings of the financial system. For example, an increase in household income, as a result of an increase in production, does not lead to more household spending and more production. Real SAM multipliers endogenize the linkages between production, income generation and spending, but the linkages between income generation, savings and investment remain exogenous. Only in FSAM multipliers, are these remaining links endogenized.

This paper constructs a SAM for Canada to measure real-financial linkages. ${ }^{4}$ We construct a SAM for Canada for 2004 using input and output tables, as well as final demand, income and

1. See Timmer and Aulin-Ahmavaara (2007) for a survey of the literature on productivity in an input-output framework.

2. See Wixted et al. (2006) for the use of harmonized OECD input-output tables.

3. See Dion et al. (2009).

4. Siddiqi and Salem (2006) compiled the first SAM for Canada using data for 2000. 
expenditure, and financial flow data for that year. Our SAM for 2004 consists of five main accounts: production activities (22 industries); factor accounts (labour, capital, mixed income, and taxes on products and production less subsidies); current accounts of institutions (households, government, non-financial enterprises, financial institutions, and rest of the world); capital accounts of institutions (households, government, non-financial enterprises, financial institutions, and rest of the world); and financial accounts (20 financial instruments).

To assess the strength of the real-financial linkages, we calculate and compare real SAM and FSAM multipliers. In particular, we ask how much larger do the multipliers become when some of the financial flows are allowed to become endogenous, so that one institution's investment in financial assets can become financial liabilities or a source of investment funds for another institution.

The advantage of using the extended input-output impact analysis to measure real-financial linkages is that it provides a simple framework, with very few assumptions, which allows the assessment of the strength of real-financial linkages by means of multipliers. Compared to dynamic stochastic general equilibrium (DSGE) models of the importance of the financial accelerator mechanism, the extended input-output framework imposes much less structure on the data. The main drawback is that the analysis is static and is based on restricting assumptions such as fixed input-output coefficients (i.e., Leontief technology). The model is, thus, subject to the Lucas critique, that as shocks shift prices, agents cannot adjust. Such a framework is, however, appropriate when looking at short-term impact as we do.

Furthermore, some exogeneity assumptions must be made in order to calculate the multipliers. Following the literature (Thorbecke and Jung 1996; Li 2008), we take the government and the rest of the world (their current and capital accounts, as well as their main financial liabilities-official reserves, government bonds, government short-term paper, and foreign investments) as exogenous. Some exogeneity assumptions are needed for two reasons. First, there must be a source for the exogenous shocks to final demand, income, or funds for investment. Second, when calculating the multipliers, there must be some leakages in the system in order to ensure that each successive round of spending is smaller than the previous one; otherwise, the multipliers would all be infinity. For example, when taxes are paid to the government, when households buy imports, when corporations invest abroad, or when financial corporations buy government bonds, these dollars disappear from the Canadian economy. Increased taxes or government bond issuance does not lead to more government spending, and higher imports and investment abroad do not cause non-residents to buy more Canadian exports. At first glance, these assumptions seem innocuous, but in reality, government and rest of the world spending is endogenous to some degree. For example, government bonds issued during this recession are likely funding spending on infrastructure projects. ${ }^{5}$ Since the goal of this paper is to illustrate the importance of real-financial linkages and not to evaluate any specific policy, refinements to the exogeneity assumptions and other parts of the model are left to future work.

The contribution of our paper is twofold. First, we build a detailed SAM for Canada for 2004 by adding income flows and financial flows to input-output data. Second, we use the SAM to obtain real-financial linkages by way of multipliers. Our results show that taking into account financial flows increases the multipliers associated with a final demand shock by $4 \%$. This is in line with the findings of Christensen and Dib (2008). Financial flows also play an important role in

5. The assumption that government is exogenous does not preclude government spending. In fact, the source of the exogenous increase in final demand or the exogenous increase in funds available to financial corporations may be part of a government policy one wished to evaluate. However, the increase in taxes paid and the government bonds purchased as a result of the exogenous government policy cannot be used to finance further government expenditures. 
determining the cumulative effect of an income shock or a shock to the availability of investment funds. The size of the effect depends, however, on the portfolio decisions of financial institutions. Between 2008 and the first half of 2009, financial institutions shifted their investments towards government bonds, short-term paper, and foreign investments. The shift towards foreign and government assets, together with the fact that non-financial institutions were unwilling or unable to increase their financial liabilities, led to estimated declines in all GDP multipliers between 2008 and the first half of $2009(2009 \mathrm{H} 1)$. The impact of a final demand shock on GDP declined $3 \%$ to $5 \%$, while the impact of an increase in the availability of investment funds fell $30 \%$ and $55 \%$ for financial and non-financial corporations, respectively.

The rest of the paper is organized as follows. In section 2, we introduce the SAM and, in section 3 , the methodology for calculating input-output, real SAM and FSAM multipliers is described. In section 4, we present the results of the multiplier analysis for Canada in 2004. In section 5, we discuss the sensitivity of multipliers to changes in the financial flows and the implications for the recent financial crisis. We conclude in section 6.

\section{The social accounting matrix (SAM)}

A schematic for the SAM used in this paper is given in Table $1 .^{6}$ The actual SAM used to calculate the multipliers is more disaggregated than shown in the schematic. For example, there are 22 industries in the actual SAM, but there are only two in the schematic. Also, in the actual SAM, firms are also split into financial and non-financial corporations, and the financial account is disaggregated into 20 financial instruments. A list of the rows and columns of the actual SAM are given in Table 2. The internal consistency of the SAM requires that five accounting identities be satisfied. The first accounting identity requires that, for each industry, total output equal total inputs. For example, the row for the goods industry gives the ways in which the total output of the goods industry is used. Some of the output is used as intermediate inputs by other industries. Other parts are consumed by households, exported, purchased by government or used as investment goods. The column for the goods industry shows the inputs used to produce the output. The goods industry uses intermediate inputs produced by itself and the service sector. It also uses primary inputs and imported inputs.

6. The actual 2004 SAM for Canada is available upon request. 
Table 1

Schematic of the Social Accounting Matrix

\begin{tabular}{|c|c|c|c|c|c|c|c|c|c|c|c|c|c|c|}
\hline & \multicolumn{2}{|c|}{ Industries } & \multicolumn{3}{|c|}{ Factor incomes } & \multicolumn{4}{|c|}{ Current account } & \multicolumn{4}{|c|}{ Capital account } & \multirow{2}{*}{$\begin{array}{c}\begin{array}{c}\text { Financial } \\
\text { account }\end{array} \\
\begin{array}{c}\text { Financial } \\
\text { instruments }\end{array} \\
\end{array}$} \\
\hline & Goods & Services & Wages & Capital & Taxes & Households & Firms & Government & $\begin{array}{c}\text { Rest of the } \\
\text { world }\end{array}$ & Households & Firms & Government & $\begin{array}{c}\text { Rest of the } \\
\text { world }\end{array}$ & \\
\hline \multicolumn{15}{|l|}{ Industries } \\
\hline Goods & \multirow{2}{*}{\multicolumn{2}{|c|}{$\begin{array}{l}\text { Intermediate } \\
\text { inputs }\end{array}$}} & $\ldots$ & $\ldots$ & $\ldots$ & \multirow{2}{*}{ Consumption } & $\ldots$ & \multirow{2}{*}{$\begin{array}{l}\text { Current } \\
\text { spending }\end{array}$} & \multirow{2}{*}{ Exports } & \multirow{2}{*}{\multicolumn{3}{|c|}{ Investment }} & $\ldots$ & $\ldots$ \\
\hline Services & & & $\ldots$ & $\ldots$ & $\ldots$ & & $\ldots$ & & & & & & $\ldots$ & $\ldots$ \\
\hline \multicolumn{15}{|c|}{ Factor incomes } \\
\hline Wages & \multicolumn{2}{|c|}{ Wages } & $\ldots$ & $\ldots$ & $\ldots$ & $\ldots$ & $\ldots$ & $\ldots$ & $\ldots$ & $\ldots$ & $\ldots$ & $\ldots$ & $\ldots$ & $\ldots$ \\
\hline Capital & \multicolumn{2}{|c|}{ Operating surplus } & $\ldots$ & $\ldots$ & $\ldots$ & $\ldots$ & $\ldots$ & $\ldots$ & $\ldots$ & $\ldots$ & $\ldots$ & $\ldots$ & $\ldots$ & $\ldots$ \\
\hline Taxes & \multicolumn{2}{|c|}{$\begin{array}{c}\text { Taxes on } \\
\text { production and } \\
\text { products, less } \\
\text { subsidies } \\
\end{array}$} & $\ldots$ & $\ldots$ & $\ldots$ & $\ldots$ & $\ldots$ & $\ldots$ & $\ldots$ & $\ldots$ & $\ldots$ & $\ldots$ & $\ldots$ & $\ldots$ \\
\hline \multicolumn{15}{|c|}{ Current account } \\
\hline Households & $\cdots$ & $\cdots$ & Wages & $\begin{array}{l}\text { Operating } \\
\text { surplus }\end{array}$ & $\cdots$ & \multirow{3}{*}{\multicolumn{4}{|c|}{ Taxes, transfers, investment income }} & $\cdots$ & $\cdots$ & $\cdots$ & $\cdots$ & $\cdots$ \\
\hline Firms & $\cdots$ & $\cdots$ & $\cdots$ & $\begin{array}{c}\text { Operating } \\
\text { surplus }\end{array}$ & $\cdots$ & & & & & $\cdots$ & $\cdots$ & $\cdots$ & $\cdots$ & $\cdots$ \\
\hline Government & $\cdots$ & $\cdots$ & $\cdots$ & $\begin{array}{l}\text { Operating } \\
\text { surplus }\end{array}$ & $\begin{array}{c}\text { Indirect } \\
\text { taxes }\end{array}$ & & & & & $\cdots$ & $\cdots$ & $\cdots$ & $\cdots$ & $\cdots$ \\
\hline $\begin{array}{l}\text { Rest of the } \\
\text { world }\end{array}$ & $\begin{array}{r}\text { Imp } \\
\text { intermedi }\end{array}$ & $\begin{array}{l}\text { orted } \\
\text { iate inputs }\end{array}$ & $\cdots$ & $\ldots$ & $\ldots$ & Imports & $\cdots$ & Imports & Reexports & Imports & Imports & Imports & $\cdots$ & $\cdots$ \\
\hline \multicolumn{15}{|c|}{ Capital account } \\
\hline Households & $\ldots$ & $\ldots$ & $\ldots$ & $\ldots$ & $\cdots$ & Savings & $\ldots$ & $\cdots$ & $\cdots$ & \multirow{4}{*}{\multicolumn{4}{|c|}{ Capital transfers }} & $\cdots$ \\
\hline Firms & $\ldots$ & $\ldots$ & $\ldots$ & $\ldots$ & $\ldots$ & $\ldots$ & Savings & $\ldots$ & $\ldots$ & & & & & $\cdots$ \\
\hline Government & $\cdots$ & $\cdots$ & $\cdots$ & $\ldots$ & $\ldots$ & $\cdots$ & $\ldots$ & Savings & $\cdots$ & & & & & $\begin{array}{l}\text { Change in } \\
\text { financial } \\
\text { liabilities }\end{array}$ \\
\hline $\begin{array}{l}\text { Rest of the } \\
\text { world }\end{array}$ & $\cdots$ & $\cdots$ & $\cdots$ & $\cdots$ & $\cdots$ & $\cdots$ & $\cdots$ & $\cdots$ & Savings & & & & & $\begin{array}{ll}\cdots \\
\text { n }\end{array}$ \\
\hline Financial & $\ldots$ & $\ldots$ & $\ldots$ & $\ldots$ & $\ldots$ & $\ldots$ & $\ldots$ & $\ldots$ & $\ldots$ & \multicolumn{4}{|c|}{ Change in financial assets } & $\ldots$ \\
\hline
\end{tabular}

Source: Statistics Canada, authors' calculations. 
Table 2

\section{List of rows and columns in the Financial Social Accounting}

Matrix

\begin{tabular}{|c|c|}
\hline & $\begin{array}{r}\text { Row and } \\
\text { column }\end{array}$ \\
\hline \multicolumn{2}{|l|}{ Industry } \\
\hline Crop and animal production & 1 \\
\hline Forestry and logging & 2 \\
\hline Fishing, hunting and trapping & 3 \\
\hline Support activities for agriculture and forestry & 4 \\
\hline Mining and oil and gas extraction & 5 \\
\hline Utilities & 6 \\
\hline Construction & 7 \\
\hline Manufacturing & 8 \\
\hline Wholesale trade & 9 \\
\hline Retail trade & 10 \\
\hline Transportation and warehousing & 11 \\
\hline Information and cultural industries & 12 \\
\hline Finance, insurance, real estate and rental and leasing & 13 \\
\hline Professional, scientific and technical services & 14 \\
\hline Administrative and support, waste management and remediation services & 15 \\
\hline Educational services & 16 \\
\hline Health care and social assistance & 17 \\
\hline Arts, entertainment and recreation & 18 \\
\hline Accommodation and food services & 19 \\
\hline Other services & 20 \\
\hline Non-profit institutions serving households & 21 \\
\hline Government sector & 22 \\
\hline \multicolumn{2}{|l|}{ Factor incomes } \\
\hline Wages & 23 \\
\hline Mixed income & 24 \\
\hline Operating surplus & 25 \\
\hline Taxes on products and production less subsidies & 26 \\
\hline \multicolumn{2}{|l|}{ Current account of institutions } \\
\hline Households & 27 \\
\hline Financial corporations & 28 \\
\hline Non-financial corporations & 29 \\
\hline Government & 30 \\
\hline Rest of World & 31 \\
\hline \multicolumn{2}{|l|}{ Capital account of institutions } \\
\hline Households & 32 \\
\hline Financial corporations & 33 \\
\hline Non-financial corporations & 34 \\
\hline Government & 35 \\
\hline Rest of World & 36 \\
\hline
\end{tabular}


Table 2

List of rows and columns in the Financial Social Accounting

Matrix (concluded)

\begin{tabular}{lr}
\hline & Row and \\
column \\
\hline Currency and bank deposits & 38 \\
Deposits in other institutions & 39 \\
Foreign currency deposits & 40 \\
Consumer credit & 41 \\
Trade accounts receivable & 42 \\
Bank loans & 43 \\
Other loans & 44 \\
Canada short-term paper & 45 \\
Other short-term paper & 46 \\
Mortgages & 47 \\
Canada bonds & 48 \\
Provincial bonds & 49 \\
Municipal bonds & 50 \\
Other Canadian bonds & 51 \\
Life insurance and pensions & 52 \\
Shares and corporate claims & 53 \\
Government claims & 54 \\
Foreign investments & 55 \\
Other financial assets & 56 \\
\hline
\end{tabular}

The second accounting identity requires that, for each income type, the income generated by all industries equal the income accruing to all institutional types (households, financial and nonfinancial corporations, government, and rest of the world). For example, wages and supplementary labour income generated by all industries (row sum) must equal income accruing to households, financial and non-financial corporations, government, and rest of the world (column sum).

The third accounting identity refers to the current account and requires that, for each institutional type, all sources of income equal all uses of income. For example, all sources of income for households, such as wages, mixed income, interest, dividends, other investment income, charitable gifts, bad debt write-offs, GST credits, child tax benefit, El benefits, etc. (row sum), must equal all uses of income, such as consumption spending on output produced by each industry, interest payments on consumer debt, income taxes, contribution to social-insurance plans, other fees, imports consumed at home and abroad, transfers, savings, and capital consumption allowance (column sum).

The fourth accounting identity refers to the capital account, and requires that, for each institutional type, savings equal investment. For example, households' savings, capital transfers, and the change in financial liabilities (row sum) must equal households' investment in housing, machine, and equipment, inventory investment, investment in imported goods, capital transfers, and the change in financial assets (column sum).

The last accounting identity requires that, for each financial instrument, the change in total assets across institutional types equal the change in total liabilities across institutions. For example, the change in the currency and deposit assets (row sum) must equal the total change in currency and deposit liabilities (column sum). 


\section{$3 \quad$ Input-output impact analysis}

In this section, we provide an overview of the input-output methodology which we will subsequently apply to the real SAM and FSAM multipliers.

The input-output model is constructed on the basis of data on interindustry flows for a given period of time, typically one year. These interindustry flows refer to the flows of products from each of the industries (as producers) to each of the industries (as purchasers). If the economy consists of $n$ industries, we denote by $z_{i j}$ the observed input flow from industry $i$ to industry $j$, by $X_{i}$ the total output of industry $i$, and by $Y_{i}$ the total final demand for the output of industry $i$. Thus, the output of industry $i$ is distributed between interindustry sales and sales to final demand:

$$
X_{i}=z_{i 1}+\ldots+z_{i n}+Y_{i},
$$

for all $i$. The technical coefficient is then defined as the dollar's worth of industry i's output needed to produce one dollar's worth of industry j's output:

$$
a_{i j}=\frac{Z_{i j}}{X_{j}}
$$

Note that the values for each $z_{i j}$ comes from the intermediate inputs block in the top left-hand corner of the SAM, or more specifically, the intersection of the first 22 rows and 22 columns of the SAM. Furthermore, $X_{j}$ is simply the column (or row) total for a particular industry in the SAM.

The main assumption in the input-output model is that of fixed technical coefficients; that is, the technical coefficients measure fixed relationships between an industry's output and its inputs. This also implies that a sector uses inputs in fixed proportions.

Substituting (2) into (1) and writing the relationship in matrix form gives:

$$
(I-A) X=Y
$$

where $I$ is the $n \times n$ identity matrix, $A=\left[a_{i j}\right]_{n \times n}$ is the matrix of technical coefficients, $X=\left[X_{i}\right]_{n \times 1}$ is the column vector of industry outputs, and $Y=\left[\underline{Y}_{i}\right]_{n \times 1}$ is the column vector of final demands. If the matrix $I-A$ is not singular, then (3) can be solved to obtain the industry outputs necessary to supply the given final demands:

$$
X=(I-A)^{-1} Y,
$$

where $(I-A)^{-1}=\left[\alpha_{i j}\right]_{n \times n}$ is referred to as the Leontief inverse.

The input flow, $z_{i j}$, from one industry to another is generally not directly observed. Instead, the matrix of technical coefficients needs to be derived from the industry by commodity output and input data.

The output data can be described in a matrix, referred to as the make matrix, the rows of which are the commodities produced by industries and the columns of which are the industry sources of commodity production. We denote the make matrix by $V=\left[v_{i k}\right]_{n \times m}$, where $v_{i k}$ is the amount of commodity $k$ produced by industry $i, n$ the number of industries, and $m$ the number of 
commodities in the economy. The elements on the diagonal of the make matrix are the primary products of an industry, while the off-diagonal elements are the secondary products. The input data can also be organized into a matrix, referred to as the use matrix, the rows of which are the destination industries of each commodity and the columns of which are the commodities used by each industry. We denote the use matrix by $U=\left[u_{k i}\right]_{m \times n}$, where $u_{k i}$ represents the amount of commodity $k$ used by industry $i$.

We denote by $Q=\left[Q_{k}\right]_{m \times 1}$ the vector of commodity gross outputs, with $Q_{k}=\sum_{i=1}^{n} v_{i k}$ and by $G=$ $\left[G_{i}\right]_{n \times 1}$ the vector of industry total outputs, with $G_{i}=\sum_{k=1}^{m} v_{i k}$.

The technical coefficients can be obtained from the use and make matrices, by use of the industry technology model. ${ }^{7}$ The industry technology model is based on the assumption that industries have a specific input structure, regardless of the composition of their outputs. Inputs can come from two sources: they can be imported or produced domestically. Therefore, imported commodities used in production need to be first removed from the use matrix. Since only imports by commodities are observed (imports by industry are not generally available), it is assumed that, if industry $i$ uses commodity $k, \mu_{k}$ of that commodity is imported, where $\mu_{k}$ is the imports of commodity $k$ available for domestic use divided by total supply of $k$ for domestic uses. ${ }^{8}$ The commodity inputs that are not imported are allocated across industries proportionally to the share of each industry in total output. If $u_{k i}$ units of commodity $k$ are used in production by industry $i$, then $\left(1-\mu_{k}\right) u_{k i}$ comes from domestic sources. Of this $\left(1-\mu_{k}\right) u_{k i}, v_{k} / Q_{k}$ is produced by industry $i$ itself and $v_{k j} / Q_{k}$ is produced by industry $j$, where $v_{k} / Q_{k}$ and $v_{k j} / Q_{k}$ are the fractions of commodity $k$ produced by industries $i$ and $j$, respectively. Therefore, the technical coefficients are given by:

$$
a_{i j}=\sum_{k=1}^{m} \frac{v_{i k}}{Q_{k}} \frac{\left(1-\mu_{k}\right) u_{k j}}{G_{j}} .
$$

We denote by "hat" the diagonal $n \times n$ matrix obtained by placing the elements of a $n \times 1$ column vector along the main diagonal. We can then obtain the matrix of technical coefficients as:

$$
A=D(I-\widehat{\mu}) B
$$

where

$$
\begin{aligned}
& D=V(\hat{Q})^{-1}, \\
& B=U(\hat{G})^{-1},
\end{aligned}
$$

7. An alternative approach to constructing technical coefficients is one based on the commodity technology model. Instead of assuming that the input structure of each industry does not depend on their commodity mixes, the commodity-based technology assumes that commodities are produced by means of the same input structure regardless of which industry produces them. On the one hand, the commodity-based technology model yields coefficients that are price-invariant. On the other hand, it may yield negative coefficients. We leave this alternative approach for future work. See ten Raa (2005) as well as Miller and Blair (2009) for more details.

8. See Ghanem (2005) for details. 
and $\mu=\left[\mu_{i}\right]_{m \times 1}$.

\subsection{Input-output multiplier effects}

One of the major uses of the input-output model is to assess the short-run impacts on all industries resulting from an increase in the final demand from one or more industries. This is referred to as impact analysis. Impact analysis in input-output models is performed with the use of multipliers. These are derived from the Leontief inverse matrix and measure the interdependencies and inter-linkages among industries. Two such multipliers are of interest: revenue multipliers and GDP multipliers.

Revenue multipliers, also referred to as output multipliers or gross output multipliers, measure the effect of an exogenous change in final demand on outputs of other sectors in the economy. The revenue multiplier for industry $j$ is defined as the total value of production in all industries necessary to meet one dollar's worth of final demand for industry j's output. The idea is that, if the output of industry $j$ increases to meet final demand, this also increases the demand from sector $j$ as a purchaser of the outputs of those industries whose products are used as inputs in the production of industry $j$. This is the first-round, or direct, effect of an increase in final demand. There is also a second-round, or indirect, effect as the supplier industries require additional inputs for their own production in order to meet the additional demand from industry $j$. Revenue multipliers, thus, measure the strength of the backward linkage of each industry and consists of both direct and indirect effects. The total-revenue multipliers are given by the column sums of the Leontief inverse:

$$
M_{j}=\sum_{i=1}^{n} \alpha_{i j}, \quad \text { for } j=1, \ldots, n \text {. }
$$

Revenue multipliers show how industries use each other's inputs as well as the linkages between a change in output in one industry and its ripple effect on others. Higher revenue multipliers indicate industries with more linkages with other industries and not necessarily those which contribute most to GDP or the most productive. The reason is that revenue multipliers double-count intermediate inputs; that is, revenue multipliers do not net out purchases that industries subsequently make from each other.

GDP multipliers correct for this double-counting and measure the total impact of an exogenous change in final demand on output. GDP multipliers are obtained from the Leontief inverse by weighing the contribution of each industry by its GDP-to-output ratio:

$$
M_{j}^{G D P}=\sum_{i} \alpha_{i j}\left(\frac{G D P}{\text { output }}\right)_{i}, \quad \text { for } j=1, \ldots, n \text {. }
$$

Since GDP multipliers net out intermediate inputs, they are typically much lower than their revenue counterparts.

\subsection{Real SAM and FSAM multipliers}

The input-output multiplier analysis can be extended to real SAM and FSAM multiplier analysis by adding endogenous sectors. The $A$ matrix for input-output multiplier analysis corresponds to 
the numbers in the intersection of the first 22 rows and columns of the SAM divided by their respective column totals. ${ }^{9}$ All other rows and columns are exogenous in the input-output analysis. The $A$ matrix for real SAM multiplier analysis, denoted $A^{S A M}$, consists of the intersection of rows and columns 1 to 25, 27 to 29, and 32 to 34. Production activities, factors incomes, and current and capital accounts for households and firms are endogenous. Taxes on production, government and rest of world current accounts, government and rest of world capital accounts, and all financial flows are exogenous.

Finally, $A^{F S A M}$, the A matrix for FSAM multiplier analysis, consists of the intersection of rows and columns 1 to 25,27 to 29,32 to 34,38 to 44,46 to 47, 51 to 54 and 56. Production activities, factors incomes, current and capital accounts for households and firms, and all financial flows except government and foreign instruments are endogenous. Taxes on production, government and rest of world current accounts, government and rest of world capital accounts, official reserves, government short-term paper and bonds, and foreign investments are exogenous.

To see the relationship between the real SAM and FSAM multipliers, it is useful to partition $A^{\text {FSAM }}$ into four blocks:

$$
A^{\text {FSAM }}=\left(\begin{array}{cc}
A^{\text {SAM }} & A_{12} \\
A_{21} & 0
\end{array}\right),
$$

where $A_{12}$ and $A_{21}$ are the matrices that border $A^{S A M}$ when extended with the financial flows block. More specifically, the $A_{12}$ matrix consists of the change in financial liabilities accounts for all instruments and all endogenous agents (the intersection of rows 1 to 25, 27 to 29, and 32 to 34 , and columns 38 to 44,46 and 47, 51 to 54, and 56). The $A_{21}$ matrix consists of the change in financial assets accounts for all instruments and all endogenous agents (the intersection of rows 38 to 44, 46 and 47, 51 to 54, and 56, and columns 1 to 25, 27 to 29, and 32 to 34). The Leontief inverse of $A^{F S A M}$ is then $\left(I-A^{F S A M}\right)^{-1}$, which, with the partition, can be written as:

$$
\left(I-A^{F S A M}\right)^{-1}=\left(\begin{array}{cc}
\left(I-A^{S A M}\right) & -A_{12} \\
-A_{21} & I
\end{array}\right)^{-1} .
$$

Denote by

$$
\left(I-A^{F S A M}\right)^{-1}=\left(\begin{array}{ll}
F_{11} & F_{12} \\
F_{21} & F_{22}
\end{array}\right),
$$

the Leontief inverse of $A^{F S A M}$. Proposition 1 shows how the FSAM multipliers are related to the real SAM multipliers.

Proposition 1

The Leontief inverse of $A^{F S A M},\left(I-A^{F S A M}\right)^{-1}$, is related to the Leontief inverse of $A^{S A M},\left(I-A^{S A M}\right)^{-1}$, by:

9. To present the SAM in a more compact form, the industry-by-commodity make and use matrices have already been transformed into industry-by-industry matrix that reflects only domestic requirements. 


$$
\begin{gathered}
F_{11}=\left[I-\left(I-A^{S A M}\right)^{-1} A_{12} A_{21}\right]^{-1}\left(I-A^{S A M}\right)^{-1}, \\
F_{22}=\left[I-A_{21}\left(I-A^{S A M}\right)^{-1} A_{12}\right]^{-1}, \\
F_{12}=F_{11} A_{12}, \\
F_{21}=F_{22} A_{21}\left(I-A^{S A M}\right)^{-1},
\end{gathered}
$$

The proof is relegated to Appendix A. Proposition 1 shows how the FSAM multipliers can be obtained from their real SAM counterparts. Equation 11 shows that financial multipliers are obtained by blowing up the real SAM multiplier matrix (or the internal multiplier matrix), $\left(I-A_{S A M}\right)^{-1}$, by a factor $\left[I-\left(I-A_{S A M}\right)^{-1} A_{12} A_{21}\right]^{-1}$. This factor is referred to as the Miyazawa external multiplier; it is basically the Leontief inverse of the $\left(I-A_{S A M}\right)^{-1} A_{12} A_{21}$ matrix (Sonis and Hewings 1999; ten Raa, 2005). The external multiplier shows the effect of a change in financial assets and liabilities, $A_{12} A_{21}$, on the real economy, $\left(I-A^{S A M}\right)^{-1}$. Equations (11) to (14) characterize the consolidated multipliers, which take into account the real production requirements $\left(I-A^{\text {SAM }}\right)^{-1}$ and also the requirements induced by the financial flows in the economy, $A_{12}$ and $A_{21}$.

It is worth noting that equations (11) to (14), which describe the relationship between the real SAM and FSAM multipliers, do not allow us to reach any definitive conclusion as to the direction of this relationship. That is, the FSAM multipliers may or may not be larger than their real SAM counterparts. The intuition is as follows. In the real SAM, an exogenous unit increase in the final demand for the output of one industry increases the income accruing to all institutions (households, financial, and non-financial). These institutions, in turn, spend the accumulated income on consumption and investment goods. In the FSAM, there is an additional loop; savings not used in capital formation is invested in financial instruments. These assets become liabilities of other institutions, increasing their source of funds for capital formation and financial investment. One would expect this last loop to generate FSAM multipliers that are higher than the real SAM ones. However, this is not necessarily the case. The real SAM and FSAM multipliers would be identical if, for example, all new financial investment were in foreign financial instruments. Since the rest of the world is taken as exogenous, there is no mechanism for this foreign investment to perhaps stimulate foreign demand for Canadian products. The FSAM multipliers can even be smaller than the real SAM ones because investment in financial assets can be negative. Consider the case where not only all new financial investment was invested abroad, but also households took existing money out of the Canadian stock market (negative financial investment in Canadian equities) and invested that abroad as well. The withdrawal of money from the Canadian stock market would shrink the pool of funds that corporations could use for investment. The question of whether taking into account the financial flows in the economy gives rise to higher multipliers and a higher output is, thus, an empirical one. We take up this question in section 4 by applying the above methodology to the 2004 data for Canada. We use the 2004 SAM to derive revenue and GDP multipliers for that year. Direct comparison of real SAM and FSAM multipliers gives us a measure of the real-financial linkages in the economy.

\section{$4 \quad$ Real and financial multiplier analysis for 2004}

CANSIM data from Statistics Canada's Input-Output accounts, Income and Expenditure accounts, and Financial Flow accounts are the primary inputs that we used to put together the FSAM. The Input-Output accounts provide the necessary information on the domestic output of each commodity by industry, the intermediate inputs and value-added inputs used by each 
industry, and the final demand for each commodity by expenditure category (for example, consumption, investment, government, exports and imports). The Income and Expenditure accounts are used to obtain the allocation and use of funds by institutional unit (households, financial corporations, non-financial corporations, government, and non-residents), and the Financial Flow accounts provide information on the changes in the financial assets and liabilities by the same institutional units.

Supplementary information from other widely available Statistics Canada data sources is also needed. For example, the Income and Expenditure accounts generally provide only total property income paid and received by each institutional unit. It does not break down the totals by institutional destination and source. We approximated this breakdown by using data on the assets and liabilities of each institution compiled in the National Balance Sheet accounts. The National Balance Sheet accounts give the assets and liabilities of each institution by asset category; the fraction of the household sector's mortgage liabilities held by each institution can be obtained, for example, by looking at the holdings of mortgage assets across institutions.

Unpublished data are also needed in some areas. For example, the splitting of operating surplus between the household and corporate sectors benefits from Rispoli (2009) calculations of GDP by unincorporated and corporate sectors. Also, the input-output accounts at a more detailed level than available on CANSIM are needed in order to split the investment expenditures of the finance, insurance, real estate, and rental and leasing industry into expenditures by the financial and non-financial sectors. ${ }^{10}$

Table 3 gives the 2004 real SAM multipliers for Canada. The industry columns show the impact of a one-unit increase in the final demand for the outputs of each of the industries. Let us consider the construction sector as an illustration. The multipliers in the column for construction indicate that a one-unit increase in the final demand for the output of the construction sector increases Canadian output by 2.59 units. The total increase in output is due to 1.08 units in the construction sector itself, 0.43 units in manufacturing, 0.29 units in finance, insurance, real estate, and rental and leasing, 0.11 units in wholesale trade, and 0.10 units in retail trade. The rest of the total output increase comes from the remaining sectors. The total-revenue multiplier for the construction industry can, for example, provide some insight into the effect of a shock to the housing market. The total-revenue multiplier for the construction sector tells us the decline in total output resulting from a one-unit decline in the final demand for the construction sector resulting from a demand shock to the housing market. For example, when a demand shock in the housing market leads to a \$1 million decline in the demand for the construction output, this would lead to a $\$ 2.59$ million decline in total output.

10. A full description of the data sources and how they were used can be provided upon request. 
Table 3

2004 Real Social Accounting Matrix revenue multipliers

\begin{tabular}{|c|c|c|c|c|c|c|c|c|c|c|}
\hline & Agriculture & Forestry & Fishing & $\begin{array}{l}\text { Primary } \\
\text { support }\end{array}$ & Mining & Utilities & Construction & Manufacturing & $\begin{array}{r}\text { Wholesale } \\
\text { trade }\end{array}$ & $\begin{array}{l}\text { Retail } \\
\text { trade }\end{array}$ \\
\hline & & & & & unit i & & & & & \\
\hline \multicolumn{11}{|l|}{ Industry } \\
\hline Agriculture & 1.23 & 0.12 & 0.02 & 0.02 & 0.01 & 0.01 & 0.03 & 0.05 & 0.02 & 0.02 \\
\hline Forestry & 0.01 & 1.07 & 0.01 & 0.01 & 0.00 & 0.01 & 0.01 & 0.03 & 0.01 & 0.01 \\
\hline Fishing & 0.00 & 0.00 & 1.01 & 0.00 & 0.00 & 0.00 & 0.00 & 0.00 & 0.00 & 0.00 \\
\hline Primary support & 0.01 & 0.01 & 0.00 & 1.00 & 0.00 & 0.00 & 0.00 & 0.00 & 0.00 & 0.00 \\
\hline Mining & 0.05 & 0.04 & 0.05 & 0.04 & 1.09 & 0.09 & 0.09 & 0.09 & 0.04 & 0.03 \\
\hline Utilities & 0.04 & 0.03 & 0.03 & 0.03 & 0.03 & 1.02 & 0.03 & 0.04 & 0.04 & 0.05 \\
\hline Construction & 0.12 & 0.09 & 0.10 & 0.08 & 0.11 & 0.13 & 1.08 & 0.07 & 0.09 & 0.09 \\
\hline Manufacturing & 0.43 & 0.33 & 0.37 & 0.35 & 0.21 & 0.20 & 0.43 & 1.41 & 0.26 & 0.25 \\
\hline Wholesale trade & 0.12 & 0.10 & 0.11 & 0.11 & 0.07 & 0.06 & 0.11 & 0.09 & 1.08 & 0.07 \\
\hline Retail trade & 0.09 & 0.10 & 0.10 & 0.11 & 0.07 & 0.08 & 0.10 & 0.07 & 0.10 & 1.11 \\
\hline Transportation & 0.09 & 0.09 & 0.07 & 0.09 & 0.05 & 0.06 & 0.07 & 0.07 & 0.09 & 0.08 \\
\hline Information & 0.06 & 0.07 & 0.06 & 0.07 & 0.05 & 0.05 & 0.06 & 0.05 & 0.10 & 0.09 \\
\hline FIREL $^{1}$ & 0.31 & 0.31 & 0.29 & 0.33 & 0.25 & 0.24 & 0.29 & 0.24 & 0.38 & 0.43 \\
\hline Professional and technical & 0.08 & 0.07 & 0.06 & 0.07 & 0.07 & 0.06 & 0.09 & 0.07 & 0.11 & 0.10 \\
\hline Administrative & 0.04 & 0.04 & 0.03 & 0.04 & 0.03 & 0.03 & 0.04 & 0.03 & 0.05 & 0.05 \\
\hline Education & 0.00 & 0.00 & 0.00 & 0.00 & 0.00 & 0.00 & 0.00 & 0.00 & 0.00 & 0.00 \\
\hline Health care & 0.02 & 0.02 & 0.02 & 0.02 & 0.01 & 0.02 & 0.02 & 0.01 & 0.02 & 0.02 \\
\hline Recreation & 0.02 & 0.02 & 0.02 & 0.02 & 0.01 & 0.01 & 0.02 & 0.01 & 0.02 & 0.02 \\
\hline Accommodation & 0.04 & 0.04 & 0.04 & 0.05 & 0.03 & 0.03 & 0.04 & 0.03 & 0.06 & 0.06 \\
\hline Other services & 0.03 & 0.03 & 0.03 & 0.04 & 0.02 & 0.02 & 0.03 & 0.02 & 0.03 & 0.03 \\
\hline Non-profit institutions & 0.02 & 0.02 & 0.02 & 0.02 & 0.02 & 0.02 & 0.02 & 0.02 & 0.02 & 0.03 \\
\hline Government & 0.03 & 0.03 & 0.03 & 0.03 & 0.03 & 0.03 & 0.03 & 0.03 & 0.04 & 0.04 \\
\hline Total & 2.87 & 2.64 & 2.46 & 2.54 & 2.17 & 2.16 & 2.59 & 2.46 & 2.56 & 2.57 \\
\hline \multicolumn{11}{|l|}{ Factor incomes } \\
\hline Wages & 0.56 & 0.67 & 0.54 & 0.79 & 0.43 & 0.51 & 0.69 & 0.54 & 0.82 & 0.88 \\
\hline Mixed & 0.16 & 0.12 & 0.28 & 0.12 & 0.05 & 0.05 & 0.11 & 0.06 & 0.09 & 0.12 \\
\hline Operating surplus & 0.57 & 0.44 & 0.37 & 0.37 & 0.81 & 0.73 & 0.36 & 0.40 & 0.48 & 0.43 \\
\hline \multicolumn{11}{|l|}{ Current account } \\
\hline Households & 0.90 & 0.93 & 0.94 & 1.03 & 0.73 & 0.79 & 0.92 & 0.73 & 1.07 & 1.14 \\
\hline Financial corporations & 0.18 & 0.15 & 0.13 & 0.13 & 0.23 & 0.22 & 0.13 & 0.13 & 0.16 & 0.15 \\
\hline Non-financial corporations & 0.43 & 0.34 & 0.28 & 0.28 & 0.61 & 0.55 & 0.28 & 0.31 & 0.37 & 0.33 \\
\hline \multicolumn{11}{|l|}{ Capital account } \\
\hline Households & 0.05 & 0.06 & 0.06 & 0.06 & 0.04 & 0.05 & 0.05 & 0.04 & 0.06 & 0.07 \\
\hline Financial corporations & 0.04 & 0.03 & 0.03 & 0.03 & 0.05 & 0.05 & 0.03 & 0.03 & 0.03 & 0.03 \\
\hline Non-financial corporations & 0.20 & 0.15 & 0.13 & 0.13 & 0.28 & 0.25 & 0.13 & 0.14 & 0.17 & 0.15 \\
\hline
\end{tabular}


Table 3

2004 Real Social Accounting Matrix revenue multipliers (continued)

\begin{tabular}{|c|c|c|c|c|c|c|c|c|c|c|}
\hline & Transportation & Information & FIREL & $\begin{array}{r}\text { Professional } \\
\text { and } \\
\text { technical } \\
\end{array}$ & Administrative & Education & Health care & Recreation & Accommodation & $\begin{array}{l}\text { Other } \\
\text { services }\end{array}$ \\
\hline & & & & & unit in & & & & & \\
\hline \multicolumn{11}{|l|}{ Industry } \\
\hline Agriculture & 0.02 & 0.02 & 0.01 & 0.02 & 0.02 & 0.02 & 0.02 & 0.02 & 0.04 & 0.02 \\
\hline Forestry & 0.01 & 0.01 & 0.01 & 0.01 & 0.01 & 0.01 & 0.01 & 0.01 & 0.01 & 0.01 \\
\hline Fishing & 0.00 & 0.00 & 0.00 & 0.00 & 0.00 & 0.00 & 0.00 & 0.00 & 0.00 & 0.00 \\
\hline Primary support & 0.00 & 0.00 & 0.00 & 0.00 & 0.00 & 0.00 & 0.00 & 0.00 & 0.00 & 0.00 \\
\hline Mining & 0.05 & 0.03 & 0.03 & 0.03 & 0.03 & 0.04 & 0.03 & 0.03 & 0.04 & 0.03 \\
\hline Utilities & 0.04 & 0.03 & 0.03 & 0.03 & 0.03 & 0.05 & 0.04 & 0.04 & 0.04 & 0.04 \\
\hline Construction & 0.10 & 0.10 & 0.12 & 0.09 & 0.09 & 0.09 & 0.09 & 0.10 & 0.09 & 0.09 \\
\hline Manufacturing & 0.32 & 0.25 & 0.20 & 0.27 & 0.27 & 0.24 & 0.26 & 0.27 & 0.40 & 0.27 \\
\hline Wholesale trade & 0.09 & 0.07 & 0.06 & 0.08 & 0.08 & 0.07 & 0.08 & 0.09 & 0.10 & 0.08 \\
\hline Retail trade & 0.11 & 0.10 & 0.09 & 0.12 & 0.11 & 0.12 & 0.12 & 0.21 & 0.11 & 0.11 \\
\hline Transportation & 1.24 & 0.08 & 0.06 & 0.08 & 0.08 & 0.07 & 0.07 & 0.08 & 0.07 & 0.07 \\
\hline Information & 0.08 & 1.11 & 0.07 & 0.10 & 0.09 & 0.08 & 0.09 & 0.09 & 0.07 & 0.08 \\
\hline FIREL $^{+}$ & 0.35 & 0.34 & 1.37 & 0.40 & 0.39 & 0.45 & 0.40 & 0.39 & 0.40 & 0.39 \\
\hline Professional and technical & 0.07 & 0.10 & 0.08 & 1.15 & 0.10 & 0.07 & 0.07 & 0.09 & 0.08 & 0.09 \\
\hline Administrative & 0.05 & 0.05 & 0.04 & 0.07 & 1.05 & 0.04 & 0.04 & 0.05 & 0.04 & 0.04 \\
\hline Education & 0.00 & 0.00 & 0.00 & 0.00 & 0.00 & 1.00 & 0.00 & 0.00 & 0.00 & 0.00 \\
\hline Health care & 0.02 & 0.02 & 0.02 & 0.02 & 0.02 & 0.02 & 1.03 & 0.02 & 0.02 & 0.02 \\
\hline Recreation & 0.02 & 0.02 & 0.02 & 0.02 & 0.02 & 0.02 & 0.02 & 1.03 & 0.02 & 0.02 \\
\hline Accommodation & 0.05 & 0.05 & 0.04 & 0.06 & 0.06 & 0.05 & 0.05 & 0.06 & 1.06 & 0.05 \\
\hline Other services & 0.04 & 0.04 & 0.03 & 0.04 & 0.04 & 0.04 & 0.03 & 0.05 & 0.03 & 1.04 \\
\hline Non-profit institutions & 0.02 & 0.02 & 0.02 & 0.03 & 0.03 & 0.03 & 0.03 & 0.03 & 0.02 & 0.03 \\
\hline Government & 0.04 & 0.03 & 0.03 & 0.04 & 0.04 & 0.04 & 0.04 & 0.04 & 0.03 & 0.04 \\
\hline Total & 2.73 & 2.48 & 2.34 & 2.66 & 2.55 & 2.55 & 2.53 & 2.71 & 2.68 & 2.54 \\
\hline \multicolumn{11}{|l|}{ Factor incomes } \\
\hline Wages & 0.81 & 0.70 & 0.55 & 0.91 & 0.90 & 0.86 & 0.76 & 0.84 & 0.81 & 0.87 \\
\hline Mixed & 0.10 & 0.08 & 0.18 & 0.17 & 0.13 & 0.32 & 0.42 & 0.12 & 0.10 & 0.13 \\
\hline Operating surplus & 0.43 & 0.56 & 0.54 & 0.39 & 0.41 & 0.35 & 0.38 & 0.43 & 0.40 & 0.42 \\
\hline \multicolumn{11}{|l|}{ Current account } \\
\hline Households & 1.06 & 0.95 & 0.90 & 1.21 & 1.16 & 1.30 & 1.32 & 1.10 & 1.04 & 1.14 \\
\hline Financial corporations & 0.15 & 0.18 & 0.17 & 0.14 & 0.15 & 0.13 & 0.14 & 0.15 & 0.14 & 0.15 \\
\hline Non-financial corporations & 0.33 & 0.43 & 0.41 & 0.30 & 0.32 & 0.27 & 0.29 & 0.33 & 0.31 & 0.32 \\
\hline \multicolumn{11}{|l|}{ Capital account } \\
\hline Households & 0.06 & 0.06 & 0.05 & 0.07 & 0.07 & 0.08 & 0.08 & 0.07 & 0.06 & 0.07 \\
\hline Financial corporations & 0.03 & 0.04 & 0.04 & 0.03 & 0.03 & 0.03 & 0.03 & 0.03 & 0.03 & 0.03 \\
\hline Non-financial corporations & 0.15 & 0.20 & 0.19 & 0.14 & 0.15 & 0.12 & 0.14 & 0.15 & 0.14 & 0.15 \\
\hline
\end{tabular}


Table 3

2004 Real Social Accounting Matrix revenue multipliers (concluded)

\begin{tabular}{|c|c|c|c|c|c|c|c|c|c|c|c|}
\hline & \multirow{2}{*}{$\begin{array}{r}\text { Non-profit } \\
\text { institutions }\end{array}$} & \multirow[t]{2}{*}{ Government } & \multicolumn{3}{|c|}{ Factor incomes } & \multicolumn{3}{|c|}{ Current account } & \multicolumn{3}{|c|}{ Capital account } \\
\hline & & & Wages & Mixed & $\begin{array}{r}\text { Operating } \\
\text { surplus }\end{array}$ & Households & $\begin{array}{r}\text { Financial } \\
\text { corporations }\end{array}$ & $\begin{array}{c}\text { Non-financial } \\
\text { corporations }\end{array}$ & Households & $\begin{array}{r}\text { Financial } \\
\text { corporations }\end{array}$ & $\begin{array}{c}\text { Non-financial } \\
\text { corporations }\end{array}$ \\
\hline & & & & & & unit increas & & & & & \\
\hline \multicolumn{12}{|l|}{ Industry } \\
\hline Agriculture & 0.02 & 0.02 & 0.02 & 0.02 & 0.01 & 0.02 & 0.01 & 0.01 & 0.02 & 0.00 & 0.01 \\
\hline Forestry & 0.01 & 0.01 & 0.01 & 0.01 & 0.00 & 0.01 & 0.00 & 0.00 & 0.01 & 0.00 & 0.00 \\
\hline Fishing & 0.00 & 0.00 & 0.00 & 0.00 & 0.00 & 0.00 & 0.00 & 0.00 & 0.00 & 0.00 & 0.00 \\
\hline Primary support & 0.00 & 0.00 & 0.00 & 0.00 & 0.00 & 0.00 & 0.00 & 0.00 & 0.00 & 0.00 & 0.00 \\
\hline Mining & 0.04 & 0.04 & 0.03 & 0.03 & 0.02 & 0.03 & 0.01 & 0.02 & 0.04 & 0.00 & 0.03 \\
\hline Utilities & 0.06 & 0.05 & 0.03 & 0.03 & 0.01 & 0.03 & 0.02 & 0.01 & 0.02 & 0.00 & 0.01 \\
\hline Construction & 0.09 & 0.11 & 0.09 & 0.09 & 0.12 & 0.09 & 0.05 & 0.15 & 0.52 & 0.00 & 0.28 \\
\hline Manufacturing & 0.26 & 0.27 & 0.24 & 0.24 & 0.13 & 0.24 & 0.11 & 0.12 & 0.24 & 0.02 & 0.17 \\
\hline Wholesale trade & 0.08 & 0.09 & 0.07 & 0.07 & 0.04 & 0.07 & 0.03 & 0.04 & 0.06 & 0.00 & 0.07 \\
\hline Retail trade & 0.12 & 0.12 & 0.13 & 0.13 & 0.06 & 0.13 & 0.06 & 0.04 & 0.06 & 0.01 & 0.05 \\
\hline Transportation & 0.08 & 0.08 & 0.06 & 0.06 & 0.03 & 0.06 & 0.03 & 0.02 & 0.04 & 0.00 & 0.03 \\
\hline Information & 0.09 & 0.08 & 0.06 & 0.06 & 0.03 & 0.06 & 0.03 & 0.02 & 0.04 & 0.00 & 0.03 \\
\hline $\mathrm{FIREL}^{+}$ & 0.40 & 0.35 & 0.39 & 0.39 & 0.16 & 0.39 & 0.17 & 0.12 & 0.23 & 0.01 & 0.12 \\
\hline Professional and technical & 0.07 & 0.08 & 0.05 & 0.05 & 0.03 & 0.05 & 0.03 & 0.03 & 0.06 & 0.00 & 0.05 \\
\hline Administrative & 0.04 & 0.04 & 0.03 & 0.03 & 0.02 & 0.03 & 0.01 & 0.01 & 0.03 & 0.00 & 0.02 \\
\hline Education & 0.00 & 0.00 & 0.00 & 0.00 & 0.00 & 0.00 & 0.00 & 0.00 & 0.00 & 0.00 & 0.00 \\
\hline Health care & 0.02 & 0.10 & 0.03 & 0.03 & 0.01 & 0.03 & 0.01 & 0.01 & 0.01 & 0.00 & 0.01 \\
\hline Recreation & 0.02 & 0.02 & 0.02 & 0.02 & 0.01 & 0.02 & 0.01 & 0.01 & 0.01 & 0.00 & 0.01 \\
\hline Accommodation & 0.06 & 0.05 & 0.06 & 0.06 & 0.02 & 0.06 & 0.03 & 0.02 & 0.02 & 0.00 & 0.02 \\
\hline Other services & 0.04 & 0.04 & 0.03 & 0.03 & 0.01 & 0.03 & 0.01 & 0.01 & 0.02 & 0.00 & 0.01 \\
\hline Non-profit institutions & 1.03 & 0.04 & 0.03 & 0.03 & 0.01 & 0.03 & 0.01 & 0.01 & 0.01 & 0.00 & 0.01 \\
\hline Government & 0.04 & 1.06 & 0.03 & 0.03 & 0.01 & 0.03 & 0.02 & 0.01 & 0.02 & 0.00 & 0.01 \\
\hline Total & 2.57 & 2.64 & 1.41 & 1.41 & 0.74 & 1.41 & 0.67 & 0.67 & 1.45 & 0.06 & 0.93 \\
\hline \multicolumn{12}{|l|}{ Factor incomes } \\
\hline Wages & 1.07 & 0.98 & 1.39 & 0.39 & 0.20 & 0.39 & 0.19 & 0.18 & 0.38 & 0.02 & 0.25 \\
\hline Mixed & 0.08 & 0.10 & 0.08 & 1.08 & 0.04 & 0.08 & 0.04 & 0.03 & 0.07 & 0.00 & 0.04 \\
\hline Operating surplus & 0.33 & 0.37 & 0.27 & 0.27 & 1.13 & 0.27 & 0.12 & 0.11 & 0.22 & 0.01 & 0.14 \\
\hline \multicolumn{12}{|l|}{ Current account } \\
\hline Households & 1.26 & 1.21 & 1.57 & 1.57 & 0.58 & 1.57 & 0.70 & 0.41 & 0.52 & 0.02 & 0.34 \\
\hline Financial corporations & 0.13 & 0.14 & 0.12 & 0.12 & 0.31 & 0.12 & 1.08 & 0.31 & 0.07 & 0.00 & 0.05 \\
\hline Non-financial corporations & 0.26 & 0.29 & 0.21 & 0.21 & 0.85 & 0.21 & 0.20 & 1.11 & 0.17 & 0.01 & 0.11 \\
\hline \multicolumn{12}{|l|}{ Capital account } \\
\hline Households & 0.08 & 0.07 & 0.09 & 0.09 & 0.03 & 0.09 & 0.04 & 0.02 & 1.03 & 0.00 & 0.02 \\
\hline Financial corporations & 0.03 & 0.03 & 0.03 & 0.03 & 0.07 & 0.03 & 0.22 & 0.06 & 0.03 & 0.99 & 0.01 \\
\hline Non-financial corporations & 0.12 & 0.13 & 0.10 & 0.10 & 0.38 & 0.10 & 0.09 & 0.50 & 0.12 & 0.00 & 1.02 \\
\hline
\end{tabular}


Table 4

2004 Financial Social Accounting Matrix revenue multipliers

\begin{tabular}{|c|c|c|c|c|c|c|c|c|c|c|}
\hline & Agriculture & Forestry & Fishing & $\begin{array}{l}\text { Primary } \\
\text { support }\end{array}$ & Mining & Utilities & Construction & Manufacturing & $\begin{array}{r}\text { Wholesale } \\
\text { trade }\end{array}$ & $\begin{array}{l}\text { Retail } \\
\text { trade }\end{array}$ \\
\hline Industry & \multicolumn{10}{|c|}{ unit increase } \\
\hline Agriculture & 1.24 & 0.12 & 0.02 & 0.02 & 0.02 & 0.02 & 0.03 & 0.05 & 0.02 & 0.02 \\
\hline Forestry & 0.01 & 1.07 & 0.01 & 0.01 & 0.01 & 0.01 & 0.01 & 0.03 & 0.01 & 0.01 \\
\hline Fishing & 0.00 & 0.00 & 1.01 & 0.00 & 0.00 & 0.00 & 0.00 & 0.00 & 0.00 & 0.00 \\
\hline Primary support & 0.01 & 0.01 & 0.00 & 1.00 & 0.00 & 0.00 & 0.00 & 0.00 & 0.00 & 0.00 \\
\hline Mining & 0.06 & 0.04 & 0.05 & 0.04 & 1.09 & 0.10 & 0.09 & 0.09 & 0.04 & 0.04 \\
\hline Utilities & 0.05 & 0.03 & 0.03 & 0.03 & 0.03 & 1.02 & 0.03 & 0.04 & 0.04 & 0.05 \\
\hline Construction & 0.15 & 0.12 & 0.13 & 0.11 & 0.16 & 0.17 & 1.10 & 0.10 & 0.13 & 0.13 \\
\hline Manufacturing & 0.46 & 0.35 & 0.39 & 0.37 & 0.23 & 0.22 & 0.45 & 1.42 & 0.28 & 0.27 \\
\hline Wholesale trade & 0.13 & 0.11 & 0.11 & 0.11 & 0.08 & 0.07 & 0.12 & 0.09 & 1.08 & 0.08 \\
\hline Retail trade & 0.10 & 0.10 & 0.11 & 0.11 & 0.08 & 0.08 & 0.10 & 0.08 & 0.11 & 1.11 \\
\hline Transportation & 0.10 & 0.09 & 0.08 & 0.10 & 0.05 & 0.06 & 0.08 & 0.08 & 0.10 & 0.09 \\
\hline Information & 0.07 & 0.07 & 0.06 & 0.07 & 0.05 & 0.05 & 0.06 & 0.05 & 0.10 & 0.09 \\
\hline FIREL $^{1}$ & 0.33 & 0.33 & 0.30 & 0.34 & 0.27 & 0.26 & 0.30 & 0.26 & 0.40 & 0.45 \\
\hline Professional and technical & 0.08 & 0.08 & 0.06 & 0.07 & 0.07 & 0.07 & 0.09 & 0.07 & 0.12 & 0.10 \\
\hline Administrative & 0.04 & 0.04 & 0.03 & 0.04 & 0.04 & 0.03 & 0.04 & 0.04 & 0.05 & 0.05 \\
\hline Education & 0.00 & 0.00 & 0.00 & 0.00 & 0.00 & 0.00 & 0.00 & 0.00 & 0.00 & 0.00 \\
\hline Health care & 0.02 & 0.02 & 0.02 & 0.02 & 0.01 & 0.02 & 0.02 & 0.01 & 0.02 & 0.02 \\
\hline Recreation & 0.02 & 0.02 & 0.02 & 0.02 & 0.01 & 0.01 & 0.02 & 0.01 & 0.02 & 0.02 \\
\hline Accommodation & 0.04 & 0.04 & 0.04 & 0.05 & 0.03 & 0.04 & 0.04 & 0.04 & 0.06 & 0.06 \\
\hline Other services & 0.03 & 0.03 & 0.03 & 0.04 & 0.02 & 0.02 & 0.03 & 0.02 & 0.03 & 0.03 \\
\hline Non-profit institutions & 0.02 & 0.02 & 0.02 & 0.03 & 0.02 & 0.02 & 0.02 & 0.02 & 0.02 & 0.03 \\
\hline Government & 0.04 & 0.03 & 0.03 & 0.04 & 0.03 & 0.04 & 0.03 & 0.03 & 0.04 & 0.04 \\
\hline Total & 2.99 & 2.74 & 2.55 & 2.64 & 2.32 & 2.30 & 2.68 & 2.54 & 2.67 & 2.68 \\
\hline \multicolumn{11}{|l|}{ Factor incomes } \\
\hline Wages & 0.59 & 0.69 & 0.56 & 0.81 & 0.47 & 0.55 & 0.71 & 0.57 & 0.85 & 0.91 \\
\hline Mixed & 0.16 & 0.13 & 0.29 & 0.13 & 0.06 & 0.06 & 0.12 & 0.06 & 0.09 & 0.12 \\
\hline Operating surplus & 0.59 & 0.46 & 0.38 & 0.39 & 0.83 & 0.75 & 0.38 & 0.42 & 0.50 & 0.44 \\
\hline \multicolumn{11}{|l|}{ Current } \\
\hline Households & 0.94 & 0.97 & 0.97 & 1.07 & 0.78 & 0.84 & 0.95 & 0.76 & 1.11 & 1.18 \\
\hline Financial corporations & 0.18 & 0.15 & 0.13 & 0.14 & 0.24 & 0.22 & 0.13 & 0.13 & 0.17 & 0.15 \\
\hline Non-financial corporations & 0.45 & 0.35 & 0.29 & 0.30 & 0.63 & 0.57 & 0.29 & 0.32 & 0.38 & 0.34 \\
\hline \multicolumn{11}{|l|}{ Capital } \\
\hline Households & 0.10 & 0.10 & 0.09 & 0.10 & 0.10 & 0.10 & 0.09 & 0.08 & 0.11 & 0.11 \\
\hline Financial corporations & 0.19 & 0.16 & 0.14 & 0.15 & 0.24 & 0.23 & 0.14 & 0.14 & 0.18 & 0.17 \\
\hline Non-financial corporations & 0.26 & 0.20 & 0.17 & 0.17 & 0.35 & 0.32 & 0.17 & 0.18 & 0.22 & 0.20 \\
\hline Financial accounts & 0.31 & 0.26 & 0.23 & 0.24 & 0.40 & 0.37 & 0.23 & 0.23 & 0.29 & 0.27 \\
\hline
\end{tabular}


Table 4

2004 Financial Social Accounting Matrix revenue multipliers (continued)

\begin{tabular}{|c|c|c|c|c|c|c|c|c|c|c|}
\hline & Transportation & Information & FIREL & $\begin{array}{r}\text { Professional } \\
\text { and } \\
\text { technical }\end{array}$ & Administrative & Education & Health care & Recreation & Accommodation & $\begin{array}{l}\text { Other } \\
\text { services }\end{array}$ \\
\hline Industry & & & & & unit in & & & & & \\
\hline Agriculture & 0.02 & 0.02 & 0.02 & 0.02 & 0.02 & 0.02 & 0.02 & 0.02 & 0.04 & 0.02 \\
\hline Forestry & 0.01 & 0.01 & 0.01 & 0.01 & 0.01 & 0.01 & 0.01 & 0.01 & 0.01 & 0.01 \\
\hline Fishing & 0.00 & 0.00 & 0.00 & 0.00 & 0.00 & 0.00 & 0.00 & 0.00 & 0.00 & 0.00 \\
\hline Primary support & 0.00 & 0.00 & 0.00 & 0.00 & 0.00 & 0.00 & 0.00 & 0.00 & 0.00 & 0.00 \\
\hline Mining & 0.05 & 0.03 & 0.03 & 0.04 & 0.04 & 0.04 & 0.04 & 0.04 & 0.04 & 0.04 \\
\hline Utilities & 0.04 & 0.03 & 0.03 & 0.04 & 0.03 & 0.05 & 0.04 & 0.04 & 0.04 & 0.04 \\
\hline Construction & 0.14 & 0.14 & 0.16 & 0.12 & 0.12 & 0.12 & 0.13 & 0.13 & 0.12 & 0.12 \\
\hline Manufacturing & 0.34 & 0.27 & 0.22 & 0.29 & 0.28 & 0.26 & 0.28 & 0.29 & 0.42 & 0.29 \\
\hline Wholesale trade & 0.09 & 0.08 & 0.07 & 0.09 & 0.08 & 0.08 & 0.09 & 0.09 & 0.10 & 0.09 \\
\hline Retail trade & 0.11 & 0.11 & 0.09 & 0.12 & 0.12 & 0.12 & 0.13 & 0.21 & 0.11 & 0.12 \\
\hline Transportation & 1.24 & 0.08 & 0.06 & 0.08 & 0.08 & 0.07 & 0.07 & 0.08 & 0.08 & 0.08 \\
\hline Information & 0.08 & 1.11 & 0.07 & 0.10 & 0.10 & 0.08 & 0.09 & 0.10 & 0.07 & 0.09 \\
\hline FIREL $^{+}$ & 0.37 & 0.36 & 1.39 & 0.41 & 0.40 & 0.46 & 0.42 & 0.41 & 0.41 & 0.41 \\
\hline Professional and technical & 0.08 & 0.11 & 0.09 & 1.15 & 0.10 & 0.08 & 0.07 & 0.10 & 0.08 & 0.09 \\
\hline Administrative & 0.05 & 0.05 & 0.04 & 0.07 & 1.05 & 0.04 & 0.04 & 0.05 & 0.04 & 0.05 \\
\hline Education & 0.00 & 0.00 & 0.00 & 0.00 & 0.00 & 1.00 & 0.00 & 0.00 & 0.00 & 0.00 \\
\hline Health care & 0.02 & 0.02 & 0.02 & 0.02 & 0.02 & 0.03 & 1.03 & 0.02 & 0.02 & 0.02 \\
\hline Recreation & 0.02 & 0.02 & 0.02 & 0.02 & 0.02 & 0.02 & 0.02 & 1.03 & 0.02 & 0.02 \\
\hline Accommodation & 0.06 & 0.05 & 0.05 & 0.06 & 0.06 & 0.06 & 0.06 & 0.06 & 1.06 & 0.05 \\
\hline Other services & 0.05 & 0.04 & 0.03 & 0.04 & 0.04 & 0.04 & 0.04 & 0.06 & 0.04 & 1.04 \\
\hline Non-profit institutions & 0.03 & 0.02 & 0.02 & 0.03 & 0.03 & 0.03 & 0.03 & 0.03 & 0.02 & 0.03 \\
\hline Government & 0.04 & 0.04 & 0.03 & 0.04 & 0.04 & 0.04 & 0.04 & 0.04 & 0.04 & 0.04 \\
\hline Total & 2.83 & 2.60 & 2.46 & 2.76 & 2.65 & 2.65 & 2.64 & 2.82 & 2.78 & 2.64 \\
\hline \multicolumn{11}{|l|}{ Factor incomes } \\
\hline Wages & 0.84 & 0.73 & 0.58 & 0.93 & 0.93 & 0.89 & 0.79 & 0.87 & 0.84 & 0.90 \\
\hline Mixed & 0.11 & 0.08 & 0.19 & 0.18 & 0.13 & 0.33 & 0.43 & 0.12 & 0.10 & 0.14 \\
\hline Operating surplus & 0.45 & 0.58 & 0.56 & 0.40 & 0.43 & 0.36 & 0.40 & 0.45 & 0.42 & 0.43 \\
\hline \multicolumn{11}{|l|}{ Current } \\
\hline Households & 1.09 & 1.00 & 0.94 & 1.25 & 1.20 & 1.34 & 1.36 & 1.14 & 1.08 & 1.18 \\
\hline Financial corporations & 0.15 & 0.18 & 0.18 & 0.15 & 0.15 & 0.14 & 0.15 & 0.15 & 0.14 & 0.15 \\
\hline Non-financial corporations & 0.34 & 0.44 & 0.42 & 0.31 & 0.33 & 0.28 & 0.31 & 0.34 & 0.32 & 0.33 \\
\hline \multicolumn{11}{|l|}{ Capital } \\
\hline Households & 0.10 & 0.10 & 0.10 & 0.11 & 0.11 & 0.12 & 0.12 & 0.11 & 0.10 & 0.11 \\
\hline Financial corporations & 0.17 & 0.19 & 0.19 & 0.16 & 0.17 & 0.16 & 0.17 & 0.17 & 0.16 & 0.17 \\
\hline Non-financial corporations & 0.20 & 0.25 & 0.24 & 0.18 & 0.19 & 0.17 & 0.18 & 0.20 & 0.19 & 0.20 \\
\hline Financial accounts & 0.27 & 0.32 & 0.30 & 0.26 & 0.27 & 0.25 & 0.27 & 0.27 & 0.25 & 0.27 \\
\hline
\end{tabular}

See bottom of table. 
Table 4

2004 Financial Social Accounting Matrix revenue multipliers (concluded)

\begin{tabular}{|c|c|c|c|c|c|c|c|c|c|c|c|}
\hline & \multirow{2}{*}{$\begin{array}{r}\text { Non-profit } \\
\text { institutions }\end{array}$} & \multirow[t]{2}{*}{ Government } & \multicolumn{3}{|c|}{ Factor incomes } & \multicolumn{3}{|c|}{ Current } & \multicolumn{3}{|c|}{ Capital } \\
\hline & & & Wages & Mixed & $\begin{array}{r}\text { Operating } \\
\text { surplus }\end{array}$ & Households & $\begin{array}{r}\text { Financial } \\
\text { corporations }\end{array}$ & $\begin{array}{c}\text { Non-financial } \\
\text { corporations }\end{array}$ & Households & $\begin{array}{r}\text { Financial } \\
\text { corporations }\end{array}$ & $\begin{array}{l}\text { Non-financial } \\
\text { corporations }\end{array}$ \\
\hline \multicolumn{12}{|c|}{ unit increase } \\
\hline \multicolumn{12}{|l|}{ Industry } \\
\hline Agriculture & 0.02 & 0.02 & 0.02 & 0.02 & 0.01 & 0.02 & 0.01 & 0.01 & 0.03 & 0.01 & 0.02 \\
\hline Forestry & 0.01 & 0.01 & 0.01 & 0.01 & 0.00 & 0.01 & 0.00 & 0.00 & 0.01 & 0.00 & 0.01 \\
\hline Fishing & 0.00 & 0.00 & 0.00 & 0.00 & 0.00 & 0.00 & 0.00 & 0.00 & 0.00 & 0.00 & 0.00 \\
\hline Primary support & 0.00 & 0.00 & 0.00 & 0.00 & 0.00 & 0.00 & 0.00 & 0.00 & 0.00 & 0.00 & 0.00 \\
\hline Mining & 0.04 & 0.04 & 0.03 & 0.03 & 0.02 & 0.03 & 0.02 & 0.02 & 0.06 & 0.03 & 0.04 \\
\hline Utilities & 0.06 & 0.05 & 0.04 & 0.04 & 0.02 & 0.04 & 0.02 & 0.01 & 0.02 & 0.01 & 0.02 \\
\hline Construction & 0.12 & 0.14 & 0.12 & 0.12 & 0.18 & 0.12 & 0.14 & 0.22 & 0.67 & 0.35 & 0.38 \\
\hline Manufacturing & 0.28 & 0.29 & 0.25 & 0.25 & 0.17 & 0.25 & 0.16 & 0.16 & 0.32 & 0.20 & 0.23 \\
\hline Wholesale trade & 0.08 & 0.09 & 0.07 & 0.07 & 0.06 & 0.07 & 0.05 & 0.06 & 0.09 & 0.06 & 0.09 \\
\hline Retail trade & 0.13 & 0.12 & 0.14 & 0.14 & 0.06 & 0.14 & 0.07 & 0.05 & 0.08 & 0.05 & 0.06 \\
\hline Transportation & 0.08 & 0.08 & 0.06 & 0.06 & 0.03 & 0.06 & 0.04 & 0.03 & 0.06 & 0.03 & 0.04 \\
\hline Information & 0.09 & 0.08 & 0.06 & 0.06 & 0.03 & 0.06 & 0.04 & 0.03 & 0.05 & 0.03 & 0.04 \\
\hline $\mathrm{FIREL}^{+}$ & 0.42 & 0.37 & 0.40 & 0.40 & 0.19 & 0.40 & 0.22 & 0.15 & 0.30 & 0.16 & 0.17 \\
\hline Professional and technical & 0.08 & 0.09 & 0.06 & 0.06 & 0.04 & 0.06 & 0.04 & 0.04 & 0.08 & 0.05 & 0.06 \\
\hline Administrative & 0.04 & 0.05 & 0.03 & 0.03 & 0.02 & 0.03 & 0.02 & 0.02 & 0.04 & 0.02 & 0.03 \\
\hline Education & 0.00 & 0.00 & 0.00 & 0.00 & 0.00 & 0.00 & 0.00 & 0.00 & 0.00 & 0.00 & 0.00 \\
\hline Health care & 0.02 & 0.10 & 0.03 & 0.03 & 0.01 & 0.03 & 0.01 & 0.01 & 0.01 & 0.01 & 0.01 \\
\hline Recreation & 0.02 & 0.02 & 0.02 & 0.02 & 0.01 & 0.02 & 0.01 & 0.01 & 0.01 & 0.01 & 0.01 \\
\hline Accommodation & 0.06 & 0.06 & 0.06 & 0.06 & 0.03 & 0.06 & 0.03 & 0.02 & 0.03 & 0.02 & 0.02 \\
\hline Other services & 0.04 & 0.04 & 0.03 & 0.03 & 0.02 & 0.03 & 0.02 & 0.01 & 0.02 & 0.01 & 0.02 \\
\hline Non-profit institutions & 1.03 & 0.04 & 0.03 & 0.03 & 0.01 & 0.03 & 0.02 & 0.01 & 0.02 & 0.01 & 0.01 \\
\hline Government & 0.04 & 1.06 & 0.04 & 0.04 & 0.02 & 0.04 & 0.02 & 0.01 & 0.03 & 0.02 & 0.02 \\
\hline Total & 2.67 & 2.74 & 1.51 & 1.51 & 0.94 & 1.51 & 0.95 & 0.90 & 1.94 & 1.11 & 1.26 \\
\hline \multicolumn{12}{|l|}{ Factor incomes } \\
\hline Wages & 1.09 & 1.01 & 1.42 & 0.42 & 0.26 & 0.42 & 0.26 & 0.25 & 0.51 & 0.30 & 0.34 \\
\hline Mixed & 0.08 & 0.11 & 0.08 & 1.08 & 0.05 & 0.08 & 0.05 & 0.04 & 0.09 & 0.05 & 0.05 \\
\hline Operating surplus & 0.35 & 0.39 & 0.28 & 0.28 & 1.16 & 0.28 & 0.17 & 0.14 & 0.29 & 0.17 & 0.19 \\
\hline \multicolumn{12}{|l|}{ Current } \\
\hline Households & 1.30 & 1.25 & 1.60 & 1.60 & 0.65 & 1.60 & 0.80 & 0.50 & 0.70 & 0.40 & 0.46 \\
\hline Financial corporations & 0.13 & 0.14 & 0.13 & 0.13 & 0.32 & 0.13 & 1.10 & 0.32 & 0.10 & 0.06 & 0.06 \\
\hline Non-financial corporations & 0.27 & 0.30 & 0.22 & 0.22 & 0.87 & 0.22 & 0.23 & 1.14 & 0.22 & 0.13 & 0.14 \\
\hline \multicolumn{12}{|l|}{ Capital } \\
\hline Households & 0.11 & 0.11 & 0.13 & 0.13 & 0.11 & 0.13 & 0.17 & 0.11 & 1.25 & 0.52 & 0.12 \\
\hline Financial corporations & 0.15 & 0.16 & 0.15 & 0.15 & 0.32 & 0.15 & 0.46 & 0.36 & 0.79 & 1.73 & 0.51 \\
\hline Non-financial corporations & 0.16 & 0.18 & 0.14 & 0.14 & 0.48 & 0.14 & 0.20 & 0.62 & 0.31 & 0.38 & 1.21 \\
\hline Financial accounts & 0.24 & 0.26 & 0.24 & 0.24 & 0.52 & 0.24 & 0.54 & 0.62 & 1.29 & 1.83 & 1.01 \\
\hline
\end{tabular}

1. Finance, insurance, real estate and rental and leasing. 
The columns for the current and capital accounts of institutions show the impact of an one-unit increase in current income and funds for investment, respectively For example, a one-unit increase in government transfers to households (current account-households' column) increases total output in the Canadian economy by 1.41 units. This is the result of households' consumption spending on the outputs produced by each industry, that is, 0.39 units on the output of finance, insurance, real estate, and rental and leasing, 0.24 units on manufacturing, and the rest on the remaining industries. Similarly, a one-unit increase in households' investment funds (capital account-households' column) results in a 1.45-unit increase in total output, of which 0.52 units in construction, 0.24 in manufacturing, 0.23 units in finance, insurance, real estate, and rental and leasing, and the rest in the remaining industries. Interestingly, a one-unit increase in the current income or investment funds of households has a much larger effect on Canadian output than a similar transfer to financial and non-financial corporations. In regard to an increase in current income, a large fraction of a household's current income is spent on consumption, while financial and non-financial corporations do not have any current spending. Instead, financial and non-financial corporations stimulate production directly through investment in physical assets. However, even here, households invest a higher fraction of their investment funds in physical assets than do corporations.

Table 4 gives the 2004 FSAM revenue multipliers for Canada. Similar to Table 3, Table 4 shows the impacts of an exogenous change in the final demand for each of the industries, and exogenous changes in current income or investment funds of institutions. For example, an exogenous one-unit increase in the final demand for the output of the construction sector induces a 2.68-unit increase in total Canadian output, of which 1.10 units in the construction sector itself, 0.45 units in manufacturing, 0.30 in finance, insurance, real estate, and rental and leasing, and the rest in the remaining industries. In addition, this generates a 0.71-unit increase in labour income, a 0.95-unit increase in household income, and a 0.09-unit increase in household savings. The increase in the savings of financial and non-financial corporations is 0.14 and 0.17 units, respectively. At the same time, a one-unit increase in final demand for construction generates a total of 0.21-unit increase in financial flows.

Similarly, a one-unit increase in government transfers to households increases Canadian output by 1.51 units, of which 0.40 units in finance, insurance, real estate, and rental and leasing, 0.25 units in manufacturing, 0.14 units in retail trade, 0.12 units in construction, and the rest coming from the remaining production activities.

Table 5 compares the 2004 total-revenue multipliers for the real SAM and FSAM. Revenue multipliers measure inter-industry linkages. The industries with the four highest revenue multipliers, both real SAM and FSAM, are crop and animal production, transportation, arts and entertainment, and professional services; these results show that these industries have the strongest linkages with the rest of the economy. Finance, insurance, real estate, and rental and leasing has one of the lowest multipliers; this reflects that this sector uses few inputs from other industries and has the fewest linkages with the rest of the economy.

Table 5 shows that in 2004 the FSAM revenue multipliers are on average 4\% larger than their real SAM counterparts. For example, a decline in the final demand for the construction sector, perhaps due to a negative demand shock to the housing market, results in a 3\% larger decline in total output when financial flows are taken into account. The reason is that the FSAM multipliers take into account the impact of financial flows on the rest of economy. In the FSAM, the savings of institutions (households, financial, and non-financial corporations) not used in physical investment is invested in financial instruments. In the real SAM, the savings not used in capital formation is not invested back into the economy and is, therefore, a leakage out of the system. In the FSAM, this savings is invested in assets which become liabilities of other 
institutions. This increases institutions' sources of funds for physical and financial investment. It is this last loop that gives rise to FSAM revenue multipliers that are larger than the real SAM ones.

Table 5

2004 revenue multipliers due to increase in final demand

\begin{tabular}{lcr}
\hline & $\begin{array}{c}\text { Social } \\
\text { Industry }\end{array}$ & $\begin{array}{c}\text { Financial Social } \\
\text { Accounting Matrix }\end{array}$ \\
\hline & unit increase & \\
Agriculture & 2.87 & 2.99 \\
Forestry & 2.64 & 2.74 \\
Fishing & 2.46 & 2.55 \\
Primary support & 2.54 & 2.64 \\
Mining & 2.17 & 2.32 \\
Utilities & 2.16 & 2.30 \\
Construction & 2.59 & 2.68 \\
Manufacturing & 2.46 & 2.54 \\
Wholesale trade & 2.56 & 2.67 \\
Retail trade & 2.57 & 2.68 \\
Transportation & 2.73 & 2.83 \\
Information & 2.48 & 2.60 \\
FIREL ${ }^{1}$ & 2.34 & 2.46 \\
Professional and technical & 2.66 & 2.76 \\
Administrative & 2.55 & 2.65 \\
Education & 2.55 & 2.65 \\
Health care & 2.53 & 2.64 \\
Recreation & 2.71 & 2.82 \\
Accommodation and food & 2.68 & 2.78 \\
Other services & 2.54 & 2.64 \\
Non-profit institutions & 2.57 & 2.67 \\
Government & 2.64 & 2.74 \\
\hline Finance, & &
\end{tabular}

1. Finance, insurance, real estate and rental and leasing.

Source: Statistics Canada, authors' calculations.

Table 6

2004 revenue multipliers due to increase in current income or funds for investment

\begin{tabular}{lcr}
\hline & $\begin{array}{c}\text { Social Accounting } \\
\text { Matrix }\end{array}$ & $\begin{array}{c}\text { Financial Social } \\
\text { Accounting Matrix }\end{array}$ \\
\hline Current & unit increase & \\
Households & & 1.51 \\
Financial corporations & 1.41 & 0.95 \\
Non-financial corporations & 0.67 & 0.90 \\
Capital & 0.67 & \\
Households & & 1.94 \\
Financial corporations & 1.45 & 1.11 \\
Non-financial corporations & 0.06 & 1.26 \\
\hline Source: Statistics Canada, authors' calculations. & 0.93 &
\end{tabular}


Table 6 shows that the 2004 FSAM revenue multipliers resulting from an increase in current income or investment funds are also larger than the real SAM multipliers. The most striking difference between the SAM and FSAM multipliers is produced by an increase in funds for investment for financial corporations. A one-unit increase in funds for investment for financial corporations produces a 0.06-unit increase in output in the SAM, compared with a 1.11-unit increase in the FSAM. The reason is that, in 2004, financial corporations invested almost all of their funds in financial assets. This effect is completely overlooked in real SAM multipliers. An exogenous increase in funds for investment has, thus, a smaller effect on Canadian output when financial flows are not accounted for.

The GDP multipliers shown in Tables 7 to 10 show a similar contrast between the real SAM and FSAM multipliers. Table 9 shows that taking into account the financial flows side of the economy produces FSAM GDP multipliers that are also on average 4\% larger than the real SAM GDP multipliers.

GDP multipliers paint a different picture than do the revenue multipliers. First, with respect to both the real SAM and the FSAM, GDP multipliers are smaller than the revenue multipliers, because they net out intermediate inputs. Second, and more importantly, the ranking of industries according to their multipliers is quite different depending on the type of multiplier being used-revenue or GDP. One notable difference is the finance, insurance, real estate, rental and leasing industry. On the one hand, finance, insurance, real estate, rental and leasing has one of the smallest revenue multipliers; this implies that it has very few backward linkages with the other industries, finance, insurance, real estate, rental and leasing uses few inputs from other industries. In contrast, finance, insurance, real estate, rental and leasing is much higher up the rankings when GDP multipliers are considered. This indicates that finance, insurance, real estate, rental and leasing makes a large contribution to Canada's overall output. ${ }^{11}$ 
Table 7

2004 Real Social Accounting Matrix GDP multipliers

\begin{tabular}{|c|c|c|c|c|c|c|c|c|c|c|}
\hline Industry & Agriculture & Forestry & Fishing & $\begin{array}{l}\text { Primary } \\
\text { support }\end{array}$ & Mining & Utilities & Construction & Manufacturing & $\begin{array}{r}\text { Wholesale } \\
\text { trade }\end{array}$ & Retail trade \\
\hline & & & & & unit inc & & & & & \\
\hline Agriculture & 0.53 & 0.05 & 0.01 & 0.01 & 0.01 & 0.01 & 0.01 & 0.02 & 0.01 & 0.01 \\
\hline Forestry & 0.01 & 0.47 & 0.00 & 0.00 & 0.00 & 0.00 & 0.00 & 0.01 & 0.00 & 0.00 \\
\hline Fishing & 0.00 & 0.00 & 0.48 & 0.00 & 0.00 & 0.00 & 0.00 & 0.00 & 0.00 & 0.00 \\
\hline Primary support & 0.01 & 0.00 & 0.00 & 0.51 & 0.00 & 0.00 & 0.00 & 0.00 & 0.00 & 0.00 \\
\hline Mining & 0.04 & 0.03 & 0.03 & 0.03 & 0.76 & 0.06 & 0.06 & 0.06 & 0.02 & 0.02 \\
\hline Utilities & 0.03 & 0.02 & 0.02 & 0.02 & 0.02 & 0.75 & 0.02 & 0.03 & 0.03 & 0.03 \\
\hline Construction & 0.05 & 0.04 & 0.04 & 0.03 & 0.04 & 0.05 & 0.43 & 0.03 & 0.04 & 0.04 \\
\hline Manufacturing & 0.13 & 0.10 & 0.11 & 0.11 & 0.06 & 0.06 & 0.13 & 0.42 & 0.08 & 0.07 \\
\hline Wholesale trade & 0.07 & 0.06 & 0.06 & 0.06 & 0.04 & 0.04 & 0.07 & 0.05 & 0.65 & 0.04 \\
\hline Retail trade & 0.06 & 0.06 & 0.07 & 0.07 & 0.05 & 0.05 & 0.06 & 0.05 & 0.07 & 0.70 \\
\hline Transportation & 0.05 & 0.05 & 0.04 & 0.05 & 0.02 & 0.03 & 0.04 & 0.04 & 0.05 & 0.04 \\
\hline Information & 0.04 & 0.04 & 0.03 & 0.04 & 0.03 & 0.03 & 0.04 & 0.03 & 0.06 & 0.05 \\
\hline FIREL $^{1}$ & 0.21 & 0.21 & 0.19 & 0.22 & 0.16 & 0.16 & 0.20 & 0.16 & 0.26 & 0.29 \\
\hline Professional and technical & 0.05 & 0.04 & 0.04 & 0.04 & 0.04 & 0.04 & 0.05 & 0.04 & 0.07 & 0.06 \\
\hline Administrative & 0.02 & 0.02 & 0.02 & 0.03 & 0.02 & 0.02 & 0.03 & 0.02 & 0.03 & 0.03 \\
\hline Education & 0.00 & 0.00 & 0.00 & 0.00 & 0.00 & 0.00 & 0.00 & 0.00 & 0.00 & 0.00 \\
\hline Health care & 0.01 & 0.01 & 0.01 & 0.02 & 0.01 & 0.01 & 0.01 & 0.01 & 0.02 & 0.02 \\
\hline Recreation & 0.01 & 0.01 & 0.01 & 0.01 & 0.01 & 0.01 & 0.01 & 0.01 & 0.01 & 0.01 \\
\hline Accommodation & 0.02 & 0.02 & 0.02 & 0.02 & 0.02 & 0.02 & 0.02 & 0.02 & 0.03 & 0.03 \\
\hline Other services & 0.02 & 0.02 & 0.02 & 0.03 & 0.01 & 0.01 & 0.02 & 0.02 & 0.02 & 0.02 \\
\hline Non-profit institutions & 0.01 & 0.01 & 0.01 & 0.02 & 0.01 & 0.01 & 0.01 & 0.01 & 0.02 & 0.02 \\
\hline Government & 0.02 & 0.02 & 0.02 & 0.02 & 0.01 & 0.02 & 0.02 & 0.02 & 0.02 & 0.02 \\
\hline Total & 1.38 & 1.30 & 1.25 & 1.34 & 1.33 & 1.37 & 1.23 & 1.05 & 1.47 & 1.52 \\
\hline
\end{tabular}

See bottom of table. 
Table 7

2004 Real Social Accounting Matrix GDP multipliers (continued)

\begin{tabular}{|c|c|c|c|c|c|c|c|c|c|c|}
\hline Industry & Transportation & Information & FIREL & Professional & Administrative & Education & Health care & Recreation & Accommodation & Other \\
\hline & \multicolumn{10}{|c|}{ unit increase } \\
\hline Agriculture & 0.01 & 0.01 & 0.01 & 0.01 & 0.01 & 0.01 & 0.01 & 0.01 & 0.02 & 0.01 \\
\hline Forestry & 0.00 & 0.00 & 0.00 & 0.00 & 0.00 & 0.00 & 0.00 & 0.00 & 0.00 & 0.00 \\
\hline Fishing & 0.00 & 0.00 & 0.00 & 0.00 & 0.00 & 0.00 & 0.00 & 0.00 & 0.00 & 0.00 \\
\hline Primary support & 0.00 & 0.00 & 0.00 & 0.00 & 0.00 & 0.00 & 0.00 & 0.00 & 0.00 & 0.00 \\
\hline Mining & 0.03 & 0.02 & 0.02 & 0.02 & 0.02 & 0.03 & 0.02 & 0.02 & 0.03 & 0.02 \\
\hline Utilities & 0.03 & 0.02 & 0.02 & 0.03 & 0.02 & 0.04 & 0.03 & 0.03 & 0.03 & 0.03 \\
\hline Construction & 0.04 & 0.04 & 0.05 & 0.04 & 0.04 & 0.04 & 0.04 & 0.04 & 0.04 & 0.04 \\
\hline Manufacturing & 0.10 & 0.08 & 0.06 & 0.08 & 0.08 & 0.07 & 0.08 & 0.08 & 0.12 & 0.08 \\
\hline Wholesale trade & 0.05 & 0.04 & 0.04 & 0.05 & 0.05 & 0.04 & 0.05 & 0.05 & 0.06 & 0.05 \\
\hline Retail trade & 0.07 & 0.06 & 0.06 & 0.07 & 0.07 & 0.07 & 0.08 & 0.13 & 0.07 & 0.07 \\
\hline Transportation & 0.61 & 0.04 & 0.03 & 0.04 & 0.04 & 0.03 & 0.03 & 0.04 & 0.04 & 0.04 \\
\hline Information & 0.05 & 0.65 & 0.04 & 0.06 & 0.06 & 0.04 & 0.05 & 0.05 & 0.04 & 0.05 \\
\hline FIREL $^{1}$ & 0.24 & 0.23 & 0.92 & 0.27 & 0.26 & 0.30 & 0.27 & 0.26 & 0.27 & 0.26 \\
\hline Professional and technical & 0.05 & 0.06 & 0.05 & 0.70 & 0.06 & 0.04 & 0.04 & 0.06 & 0.05 & 0.05 \\
\hline Administrative & 0.03 & 0.03 & 0.03 & 0.04 & 0.68 & 0.03 & 0.02 & 0.03 & 0.03 & 0.03 \\
\hline Education & 0.00 & 0.00 & 0.00 & 0.00 & 0.00 & 0.74 & 0.00 & 0.00 & 0.00 & 0.00 \\
\hline Health care & 0.02 & 0.01 & 0.01 & 0.02 & 0.02 & 0.02 & 0.80 & 0.02 & 0.02 & 0.02 \\
\hline Recreation & 0.01 & 0.01 & 0.01 & 0.01 & 0.01 & 0.01 & 0.01 & 0.52 & 0.01 & 0.01 \\
\hline Accommodation & 0.03 & 0.02 & 0.02 & 0.03 & 0.03 & 0.03 & 0.03 & 0.03 & 0.52 & 0.03 \\
\hline Other services & 0.03 & 0.03 & 0.02 & 0.02 & 0.02 & 0.02 & 0.02 & 0.03 & 0.02 & 0.66 \\
\hline Non-profit institutions & 0.02 & 0.02 & 0.01 & 0.02 & 0.02 & 0.02 & 0.02 & 0.02 & 0.02 & 0.02 \\
\hline Government & 0.02 & 0.02 & 0.02 & 0.02 & 0.02 & 0.02 & 0.02 & 0.02 & 0.02 & 0.02 \\
\hline Total & 1.43 & 1.40 & 1.42 & 1.53 & 1.51 & 1.61 & 1.64 & 1.46 & 1.39 & 1.49 \\
\hline
\end{tabular}

See bottom of table. 
Table 7

2004 Real Social Accounting Matrix GDP multipliers (concluded)

\begin{tabular}{|c|c|c|c|c|c|c|c|c|c|c|c|}
\hline \multirow[b]{2}{*}{ Industry } & \multirow{2}{*}{$\begin{array}{r}\text { Non-profit } \\
\text { institutions }\end{array}$} & \multirow[t]{2}{*}{ Government } & \multicolumn{3}{|c|}{ Factor incomes } & \multicolumn{3}{|c|}{ Current } & \multicolumn{3}{|c|}{ Capital } \\
\hline & & & Wages & Mixed & $\begin{array}{r}\text { Operating } \\
\text { surplus } \\
\end{array}$ & Households & $\begin{array}{r}\text { Financial } \\
\text { corporations }\end{array}$ & $\begin{array}{c}\text { Non-financial } \\
\text { corporations }\end{array}$ & Households & $\begin{array}{r}\text { Financial } \\
\text { corporations }\end{array}$ & $\begin{array}{l}\text { Non-financial } \\
\text { corporations }\end{array}$ \\
\hline & & & & & & unit increase & & & & & \\
\hline Agriculture & 0.01 & 0.01 & 0.01 & 0.01 & 0.00 & 0.01 & 0.00 & 0.00 & 0.01 & 0.00 & 0.01 \\
\hline Forestry & 0.00 & 0.00 & 0.00 & 0.00 & 0.00 & 0.00 & 0.00 & 0.00 & 0.00 & 0.00 & 0.00 \\
\hline Fishing & 0.00 & 0.00 & 0.00 & 0.00 & 0.00 & 0.00 & 0.00 & 0.00 & 0.00 & 0.00 & 0.00 \\
\hline Primary support & 0.00 & 0.00 & 0.00 & 0.00 & 0.00 & 0.00 & 0.00 & 0.00 & 0.00 & 0.00 & 0.00 \\
\hline Mining & 0.03 & 0.03 & 0.02 & 0.02 & 0.01 & 0.02 & 0.01 & 0.01 & 0.03 & 0.00 & 0.02 \\
\hline Utilities & 0.04 & 0.03 & 0.03 & 0.03 & 0.01 & 0.03 & 0.01 & 0.01 & 0.01 & 0.00 & 0.01 \\
\hline Construction & 0.04 & 0.04 & 0.03 & 0.03 & 0.05 & 0.03 & 0.02 & 0.06 & 0.21 & 0.00 & 0.11 \\
\hline Manufacturing & 0.08 & 0.08 & 0.07 & 0.07 & 0.04 & 0.07 & 0.03 & 0.04 & 0.07 & 0.01 & 0.05 \\
\hline Wholesale trade & 0.05 & 0.05 & 0.04 & 0.04 & 0.03 & 0.04 & 0.02 & 0.03 & 0.04 & 0.00 & 0.04 \\
\hline Retail trade & 0.08 & 0.08 & 0.08 & 0.08 & 0.04 & 0.08 & 0.04 & 0.03 & 0.04 & 0.00 & 0.03 \\
\hline Transportation & 0.04 & 0.04 & 0.03 & 0.03 & 0.01 & 0.03 & 0.01 & 0.01 & 0.02 & 0.00 & 0.02 \\
\hline Information & 0.05 & 0.05 & 0.03 & 0.03 & 0.02 & 0.03 & 0.02 & 0.01 & 0.02 & 0.00 & 0.02 \\
\hline $\mathrm{FIREL}^{1}$ & 0.27 & 0.24 & 0.26 & 0.26 & 0.10 & 0.26 & 0.12 & 0.08 & 0.15 & 0.00 & 0.08 \\
\hline Professional and technical & 0.04 & 0.05 & 0.03 & 0.03 & 0.02 & 0.03 & 0.02 & 0.02 & 0.04 & 0.00 & 0.03 \\
\hline Administrative & 0.03 & 0.03 & 0.02 & 0.02 & 0.01 & 0.02 & 0.01 & 0.01 & 0.02 & 0.00 & 0.01 \\
\hline Education & 0.00 & 0.00 & 0.00 & 0.00 & 0.00 & 0.00 & 0.00 & 0.00 & 0.00 & 0.00 & 0.00 \\
\hline Health care & 0.02 & 0.08 & 0.02 & 0.02 & 0.01 & 0.02 & 0.01 & 0.01 & 0.01 & 0.00 & 0.01 \\
\hline Recreation & 0.01 & 0.01 & 0.01 & 0.01 & 0.00 & 0.01 & 0.00 & 0.00 & 0.00 & 0.00 & 0.00 \\
\hline Accommodation & 0.03 & 0.03 & 0.03 & 0.03 & 0.01 & 0.03 & 0.01 & 0.01 & 0.01 & 0.00 & 0.01 \\
\hline Other services & 0.02 & 0.02 & 0.02 & 0.02 & 0.01 & 0.02 & 0.01 & 0.01 & 0.01 & 0.00 & 0.01 \\
\hline Non-profit institutions & 0.69 & 0.02 & 0.02 & 0.02 & 0.01 & 0.02 & 0.01 & 0.01 & 0.01 & 0.00 & 0.01 \\
\hline Government & 0.02 & 0.64 & 0.02 & 0.02 & 0.01 & 0.02 & 0.01 & 0.01 & 0.01 & 0.00 & 0.01 \\
\hline Total & 1.55 & 1.52 & 0.79 & 0.79 & 0.39 & 0.79 & 0.37 & 0.35 & 0.71 & 0.03 & 0.46 \\
\hline
\end{tabular}

1. Finance, insurance, real estate and rental and leasing.

Source: Statistics Canada, authors' calculations. 
Table 8

2004 Financial Social Accounting Matrix GDP multipliers

\begin{tabular}{|c|c|c|c|c|c|c|c|c|c|c|}
\hline Industry & Agriculture & Forestry & Fishing & $\begin{array}{l}\text { Primary } \\
\text { support }\end{array}$ & Mining & Utilities & Construction & Manufacturing & $\begin{array}{r}\text { Wholesale } \\
\text { trade }\end{array}$ & Retail trade \\
\hline & \multicolumn{10}{|c|}{ unit increase } \\
\hline Agriculture & 0.53 & 0.05 & 0.01 & 0.01 & 0.01 & 0.01 & 0.01 & 0.02 & 0.01 & 0.01 \\
\hline Forestry & 0.01 & 0.48 & 0.00 & 0.00 & 0.00 & 0.00 & 0.00 & 0.01 & 0.00 & 0.00 \\
\hline Fishing & 0.00 & 0.00 & 0.48 & 0.00 & 0.00 & 0.00 & 0.00 & 0.00 & 0.00 & 0.00 \\
\hline Primary support & 0.01 & 0.00 & 0.00 & 0.51 & 0.00 & 0.00 & 0.00 & 0.00 & 0.00 & 0.00 \\
\hline Mining & 0.04 & 0.03 & 0.04 & 0.03 & 0.76 & 0.07 & 0.06 & 0.07 & 0.03 & 0.03 \\
\hline Utilities & 0.03 & 0.02 & 0.02 & 0.03 & 0.03 & 0.75 & 0.02 & 0.03 & 0.03 & 0.03 \\
\hline Construction & 0.06 & 0.05 & 0.05 & 0.04 & 0.06 & 0.07 & 0.44 & 0.04 & 0.05 & 0.05 \\
\hline Manufacturing & 0.14 & 0.10 & 0.12 & 0.11 & 0.07 & 0.07 & 0.14 & 0.43 & 0.08 & 0.08 \\
\hline Wholesale trade & 0.08 & 0.07 & 0.07 & 0.07 & 0.05 & 0.04 & 0.07 & 0.06 & 0.65 & 0.05 \\
\hline Retail trade & 0.06 & 0.07 & 0.07 & 0.07 & 0.05 & 0.05 & 0.07 & 0.05 & 0.07 & 0.71 \\
\hline Transportation & 0.05 & 0.05 & 0.04 & 0.05 & 0.03 & 0.03 & 0.04 & 0.04 & 0.05 & 0.04 \\
\hline Information & 0.04 & 0.04 & 0.03 & 0.04 & 0.03 & 0.03 & 0.04 & 0.03 & 0.06 & 0.06 \\
\hline FIREL $^{\perp}$ & 0.22 & 0.22 & 0.20 & 0.23 & 0.18 & 0.18 & 0.20 & 0.17 & 0.27 & 0.30 \\
\hline Professional and technical & 0.05 & 0.05 & 0.04 & 0.04 & 0.04 & 0.04 & 0.06 & 0.05 & 0.07 & 0.06 \\
\hline Administrative & 0.03 & 0.02 & 0.02 & 0.03 & 0.02 & 0.02 & 0.03 & 0.02 & 0.04 & 0.03 \\
\hline Education & 0.00 & 0.00 & 0.00 & 0.00 & 0.00 & 0.00 & 0.00 & 0.00 & 0.00 & 0.00 \\
\hline Health care & 0.01 & 0.01 & 0.01 & 0.02 & 0.01 & 0.01 & 0.01 & 0.01 & 0.02 & 0.02 \\
\hline Recreation & 0.01 & 0.01 & 0.01 & 0.01 & 0.01 & 0.01 & 0.01 & 0.01 & 0.01 & 0.01 \\
\hline Accommodation & 0.02 & 0.02 & 0.02 & 0.02 & 0.02 & 0.02 & 0.02 & 0.02 & 0.03 & 0.03 \\
\hline Other services & 0.02 & 0.02 & 0.02 & 0.03 & 0.02 & 0.01 & 0.02 & 0.02 & 0.02 & 0.02 \\
\hline Non-profit institutions & 0.01 & 0.01 & 0.01 & 0.02 & 0.01 & 0.01 & 0.01 & 0.01 & 0.02 & 0.02 \\
\hline Government & 0.02 & 0.02 & 0.02 & 0.02 & 0.02 & 0.02 & 0.02 & 0.02 & 0.02 & 0.02 \\
\hline Total & 1.44 & 1.35 & 1.29 & 1.39 & 1.41 & 1.44 & 1.28 & 1.09 & 1.52 & 1.57 \\
\hline
\end{tabular}

See bottom of table. 
Table 8

2004 Financial Social Accounting Matrix GDP multipliers (continued)

\begin{tabular}{|c|c|c|c|c|c|c|c|c|c|c|}
\hline Industry & Transportation & Information & FIREL $^{1}$ & $\begin{array}{r}\text { Professional } \\
\text { and } \\
\text { technical }\end{array}$ & Administrative & Education & Health care & Recreation & Accommodation & $\begin{array}{r}\text { Other } \\
\text { services }\end{array}$ \\
\hline & & & & & unit incre & & & & & \\
\hline Agriculture & 0.01 & 0.01 & 0.01 & 0.01 & 0.01 & 0.01 & 0.01 & 0.01 & 0.02 & 0.01 \\
\hline Forestry & 0.00 & 0.00 & 0.00 & 0.00 & 0.00 & 0.00 & 0.00 & 0.00 & 0.00 & 0.00 \\
\hline Fishing & 0.00 & 0.00 & 0.00 & 0.00 & 0.00 & 0.00 & 0.00 & 0.00 & 0.00 & 0.00 \\
\hline Primary support & 0.00 & 0.00 & 0.00 & 0.00 & 0.00 & 0.00 & 0.00 & 0.00 & 0.00 & 0.00 \\
\hline Mining & 0.03 & 0.02 & 0.02 & 0.03 & 0.03 & 0.03 & 0.03 & 0.03 & 0.03 & 0.03 \\
\hline Utilities & 0.03 & 0.02 & 0.02 & 0.03 & 0.03 & 0.04 & 0.03 & 0.03 & 0.03 & 0.03 \\
\hline Construction & 0.05 & 0.05 & 0.06 & 0.05 & 0.05 & 0.05 & 0.05 & 0.05 & 0.05 & 0.05 \\
\hline Manufacturing & 0.10 & 0.08 & 0.07 & 0.09 & 0.09 & 0.08 & 0.08 & 0.09 & 0.13 & 0.09 \\
\hline Wholesale trade & 0.05 & 0.05 & 0.04 & 0.05 & 0.05 & 0.05 & 0.05 & 0.06 & 0.06 & 0.05 \\
\hline Retail trade & 0.07 & 0.07 & 0.06 & 0.08 & 0.08 & 0.08 & 0.08 & 0.13 & 0.07 & 0.07 \\
\hline Transportation & 0.61 & 0.04 & 0.03 & 0.04 & 0.04 & 0.04 & 0.04 & 0.04 & 0.04 & 0.04 \\
\hline Information & 0.05 & 0.65 & 0.04 & 0.06 & 0.06 & 0.05 & 0.05 & 0.06 & 0.04 & 0.05 \\
\hline FIREL $^{1}$ & 0.25 & 0.24 & 0.93 & 0.28 & 0.27 & 0.31 & 0.28 & 0.27 & 0.28 & 0.27 \\
\hline Professional and technical & 0.05 & 0.07 & 0.05 & 0.70 & 0.06 & 0.05 & 0.05 & 0.06 & 0.05 & 0.06 \\
\hline Administrative & 0.03 & 0.03 & 0.03 & 0.04 & 0.68 & 0.03 & 0.03 & 0.03 & 0.03 & 0.03 \\
\hline Education & 0.00 & 0.00 & 0.00 & 0.00 & 0.00 & 0.74 & 0.00 & 0.00 & 0.00 & 0.00 \\
\hline Health care & 0.02 & 0.01 & 0.01 & 0.02 & 0.02 & 0.02 & 0.80 & 0.02 & 0.02 & 0.02 \\
\hline Recreation & 0.01 & 0.01 & 0.01 & 0.01 & 0.01 & 0.01 & 0.01 & 0.52 & 0.01 & 0.01 \\
\hline Accommodation & 0.03 & 0.02 & 0.02 & 0.03 & 0.03 & 0.03 & 0.03 & 0.03 & 0.52 & 0.03 \\
\hline Other services & 0.03 & 0.03 & 0.02 & 0.02 & 0.03 & 0.02 & 0.02 & 0.04 & 0.02 & 0.66 \\
\hline Non-profit institutions & 0.02 & 0.02 & 0.01 & 0.02 & 0.02 & 0.02 & 0.02 & 0.02 & 0.02 & 0.02 \\
\hline Government & 0.02 & 0.02 & 0.02 & 0.03 & 0.02 & 0.02 & 0.02 & 0.02 & 0.02 & 0.02 \\
\hline Total & 1.48 & 1.46 & 1.48 & 1.58 & 1.56 & 1.66 & 1.69 & 1.51 & 1.43 & 1.54 \\
\hline
\end{tabular}

See bottom of table. 
Table 8

2004 Financial Social Accounting Matrix GDP multipliers (concluded)

\begin{tabular}{|c|c|c|c|c|c|c|}
\hline \multirow{2}{*}{$\begin{array}{l}\text { Non-profit Government } \\
\text { institutions }\end{array}$} & Factor incomes & \multicolumn{3}{|c|}{ Current } & \multicolumn{2}{|r|}{ Capital } \\
\hline & Wages & $\begin{array}{l}\text { Operating Households } \\
\text { surplus }\end{array}$ & $\begin{array}{r}\text { Financial } \\
\text { corporations }\end{array}$ & $\begin{array}{l}\text { Non-financial } \\
\text { corporations }\end{array}$ & Households & $\begin{array}{rr}\text { Financial } & \text { Non-financial } \\
\text { corporations } & \text { corporations }\end{array}$ \\
\hline
\end{tabular}

Industry

unit increase

\begin{tabular}{|c|c|c|c|c|c|c|c|c|c|c|c|}
\hline Agriculture & 0.01 & 0.01 & 0.01 & 0.01 & 0.01 & 0.01 & 0.01 & 0.01 & 0.01 & 0.01 & 0.01 \\
\hline Forestry & 0.00 & 0.00 & 0.00 & 0.00 & 0.00 & 0.00 & 0.00 & 0.00 & 0.00 & 0.00 & 0.00 \\
\hline Fishing & 0.00 & 0.00 & 0.00 & 0.00 & 0.00 & 0.00 & 0.00 & 0.00 & 0.00 & 0.00 & 0.00 \\
\hline Primary support & 0.00 & 0.00 & 0.00 & 0.00 & 0.00 & 0.00 & 0.00 & 0.00 & 0.00 & 0.00 & 0.00 \\
\hline Mining & 0.03 & 0.03 & 0.02 & 0.02 & 0.02 & 0.02 & 0.02 & 0.02 & 0.04 & 0.02 & 0.03 \\
\hline Utilities & 0.05 & 0.03 & 0.03 & 0.03 & 0.01 & 0.03 & 0.01 & 0.01 & 0.02 & 0.01 & 0.01 \\
\hline Construction & 0.05 & 0.05 & 0.05 & 0.05 & 0.07 & 0.05 & 0.06 & 0.09 & 0.27 & 0.14 & 0.15 \\
\hline Manufacturing & 0.08 & 0.09 & 0.08 & 0.08 & 0.05 & 0.08 & 0.05 & 0.05 & 0.10 & 0.06 & 0.07 \\
\hline Wholesale trade & 0.05 & 0.05 & 0.04 & 0.04 & 0.03 & 0.04 & 0.03 & 0.03 & 0.05 & 0.04 & 0.05 \\
\hline Retail trade & 0.08 & 0.08 & 0.09 & 0.09 & 0.04 & 0.09 & 0.05 & 0.03 & 0.05 & 0.03 & 0.04 \\
\hline Transportation & 0.04 & 0.04 & 0.03 & 0.03 & 0.02 & 0.03 & 0.02 & 0.02 & 0.03 & 0.02 & 0.02 \\
\hline Information & 0.05 & 0.05 & 0.04 & 0.04 & 0.02 & 0.04 & 0.02 & 0.02 & 0.03 & 0.02 & 0.02 \\
\hline FIREL $^{1}$ & 0.28 & 0.24 & 0.27 & 0.27 & 0.12 & 0.27 & 0.15 & 0.10 & 0.20 & 0.11 & 0.11 \\
\hline Professional and technical & 0.05 & 0.05 & 0.03 & 0.03 & 0.03 & 0.03 & 0.02 & 0.03 & 0.05 & 0.03 & 0.04 \\
\hline Administrative & 0.03 & 0.03 & 0.02 & 0.02 & 0.01 & 0.02 & 0.01 & 0.01 & 0.02 & 0.01 & 0.02 \\
\hline Education & 0.00 & 0.00 & 0.00 & 0.00 & 0.00 & 0.00 & 0.00 & 0.00 & 0.00 & 0.00 & 0.00 \\
\hline Health care & 0.02 & 0.08 & 0.02 & 0.02 & 0.01 & 0.02 & 0.01 & 0.01 & 0.01 & 0.01 & 0.01 \\
\hline Recreation & 0.01 & 0.01 & 0.01 & 0.01 & 0.00 & 0.01 & 0.00 & 0.00 & 0.01 & 0.00 & 0.00 \\
\hline Accommodation & 0.03 & 0.03 & 0.03 & 0.03 & 0.01 & 0.03 & 0.02 & 0.01 & 0.02 & 0.01 & 0.01 \\
\hline Other services & 0.02 & 0.02 & 0.02 & 0.02 & 0.01 & 0.02 & 0.01 & 0.01 & 0.01 & 0.01 & 0.01 \\
\hline Non-profit institutions & 0.69 & 0.02 & 0.02 & 0.02 & 0.01 & 0.02 & 0.01 & 0.01 & 0.01 & 0.01 & 0.01 \\
\hline Government & 0.02 & 0.64 & 0.02 & 0.02 & 0.01 & 0.02 & 0.01 & 0.01 & 0.02 & 0.01 & 0.01 \\
\hline Total & 1.60 & 1.57 & 0.84 & 0.84 & 0.49 & 0.84 & 0.51 & 0.46 & 0.95 & 0.54 & 0.62 \\
\hline
\end{tabular}

1. Finance, insurance, real estate and rental and leasing.

Source: Statistics Canada, authors' calculations. 
Table 9

2004 GDP multipliers due to increase in final demand

\begin{tabular}{lcc}
\hline Industry & $\begin{array}{c}\text { Social } \\
\text { Accounting } \\
\text { Matrix }\end{array}$ & $\begin{array}{c}\text { Financial Social } \\
\text { Accounting Matrix }\end{array}$ \\
\hline Agriculture & unit increase & 1.44 \\
Forestry & 1.38 & 1.35 \\
Fishing & 1.30 & 1.29 \\
Primary support & 1.25 & 1.39 \\
Mining & 1.34 & 1.41 \\
Utilities & 1.33 & 1.44 \\
Construction & 1.37 & 1.28 \\
Manufacturing & 1.23 & 1.09 \\
Wholesale trade & 1.05 & 1.52 \\
Retail trade & 1.47 & 1.57 \\
Transportation & 1.52 & 1.48 \\
Information & 1.43 & 1.46 \\
Finance, insurance, real estate and rental and leasing & 1.40 & 1.48 \\
Professional and technical & 1.42 & 1.58 \\
Administrative & 1.53 & 1.56 \\
Education & 1.51 & 1.66 \\
Health care & 1.61 & 1.69 \\
Recreation & 1.64 & 1.51 \\
Accommodation and food & 1.46 & 1.43 \\
Other services & 1.39 & 1.54 \\
Non-profit institutions & 1.49 & 1.60 \\
Government & 1.55 & 1.57 \\
\hline Source: Stalsics Canada, aut & 1.52 & \\
\hline
\end{tabular}

Source: Statistics Canada, authors' calculations.

Table 10

2004 GDP multipliers due to increase in current income or funds for investment

\begin{tabular}{lcc}
\hline & $\begin{array}{c}\text { Social Accounting } \\
\text { Matrix }\end{array}$ & $\begin{array}{r}\text { Financial Social } \\
\text { Accounting Matrix }\end{array}$ \\
\hline unit increase & \\
Households & & 0.84 \\
Financial corporations & 0.79 & 0.51 \\
Non-financial corporations & 0.37 & 0.46 \\
Capital & 0.35 & 0.95 \\
Households & & 0.54 \\
Financial corporations & 0.71 & 0.62 \\
Non-financial corporations & 0.03 & \\
\hline
\end{tabular}

Source: Statistics Canada, authors' calculations.

Both the revenue and GDP multipliers due to an increase in current income and funds for investment display a significant difference from their financial counterparts, as shown in Tables 
6 and 10. Since an increase in investment funds to financial corporations has a significant impact on total Canadian output, it raises the question of how effective a monetary policy designed to increase investment funds to financial corporations would be. More specifically, the size of the impact of an increase in the availability of investment funds depends on the portfolio decisions of financial corporations. If financial corporations invest the additional funds back into domestic assets, the aforementioned policy has a larger impact on total output than it does when these investments are made in foreign assets. Investments in foreign assets are a leakage out of the domestic economy and dampen the effect of an increase in the availability of funds for investment.

\section{The sensitivity of multipliers to changes in the financial flows and the impact of the recent financial crisis}

Although the real part of the FSAM can be thought of as something that evolves gradually over time, the financial flows part of the matrix naturally displays a much higher degree of variability. Evidence of this higher variability can be seen by comparing the coefficient of variations of the real SAM and FSAM multipliers for the years 2000 to 2005 (Table 11). For all industries, the FSAM multipliers have a higher coefficient of variation than do the corresponding real SAM multipliers. On average, the coefficients of variation from the FSAM multipliers are 25 percent higher than those from the real SAM multipliers.

Another characteristic of the financial flows data is that they are timelier than the input-output data. While the annual input-output accounts are available with a three-year lag, the financial flows data are available quarterly with a two-month lag. This raises the question of whether it is possible to see how the latest changes in the financial flows data affect the multipliers.

Altering the technical coefficients associated with the changes in financial liabilities (block $A_{12}$ ) is straightforward, as the only data that appear in those columns are data from the financial flows. The distribution of liabilities across endogenous institutional types for each endogenous asset category from the most recent financial flows release can be simply substituted for the preexisting data. Changing the technical coefficients associated with changes in financial assets is more complex because those columns also involve the information on investment in fixed assets and capital transfers. Here, the technical coefficients involving fixed assets and capital transfers would remain the same as in the pre-existing technical coefficient matrix, as would the sum of the technical coefficients related to financial investments within each institution. Only the distribution across financial investments would change. For example, let us suppose that, in the existing matrix, one-half of the household sector's investment funds went into fixed assets, onequarter went into bank deposits, and one-quarter went into shares. The most recent financial flows data might show a significant drop in the level of financial investment, and a change in the distribution of financial investment toward more bank deposits. Since information for fixed investment for the most recent period is not yet available, it is assumed that the distribution between fixed and financial investment remains the same. However, the distribution across financial investments is allowed to change in order to reflect the greater investment in bank deposits relative to shares. 
Table 11

Coefficient of variation for total GDP multipliers by industry, 2000 to 2005

\begin{tabular}{lcc}
\hline Industry & $\begin{array}{c}\text { Social } \\
\text { Accounting } \\
\text { Matrix }\end{array}$ & $\begin{array}{c}\text { Financial Social } \\
\text { Accounting Matrix }\end{array}$ \\
\hline Agriculture & percent & \\
Forestry & 1.38 & 1.44 \\
Fishing & 1.30 & 1.35 \\
Primary support & 1.25 & 1.29 \\
Mining & 1.34 & 1.39 \\
Utilities & 1.33 & 1.41 \\
Construction & 1.37 & 1.44 \\
Manufacturing & 1.23 & 1.28 \\
Wholesale trade & 1.05 & 1.09 \\
Retail trade & 1.47 & 1.52 \\
Transportation & 1.52 & 1.57 \\
Information & 1.43 & 1.48 \\
Finance, insurance, real estate and rental and leasing & 1.40 & 1.46 \\
Professional and technical & 1.42 & 1.48 \\
Administrative & 1.53 & 1.58 \\
Education & 1.51 & 1.56 \\
Health care & 1.61 & 1.66 \\
Recreation & 1.64 & 1.69 \\
Accommodation and food & 1.46 & 1.51 \\
Other services & 1.39 & 1.43 \\
Non-profit institutions & 1.49 & 1.54 \\
Government & 1.55 & 1.60 \\
\hline
\end{tabular}

Source: Statistics Canada, authors' calculations.

Chart 1 plots the total GDP FSAM multipliers for manufacturing from 1961 to $2009 \mathrm{H} 1$. The multiplier for 2004 is the same as reported in Table 9 and is calculated entirely from 2004 data. The remaining multipliers are computed as described in the preceding paragraph. The technical coefficients related to the financial flows are changed in order to reflect the evolution of the distribution of financial investments across asset categories and the distribution of financial liabilities across institutions; however, the remaining technical coefficients are held at their 2004 values. The most remarkable feature of Chart 1 is the $5 \%$ drop in the multiplier in 2009. Although the multiplier also declined noticeably during the 1970 and 1982 recessions, the decline that took place in 2009 was much more prominent.

The effect of the financial crisis on the multiplier for manufacturing was not unique, as the multiplier for other industries were similarly affected. Table 12 presents the declines in the total GDP FSAM multipliers by industry. Between 2008 and the first two quarters of 2009, each total GDP multiplier declined by $3 \%$ to $5 \%$. 
Table 12

Total GDP multipliers by industry, change between 2008 and the first half of 2009

\begin{tabular}{lr}
\hline Industry & $\begin{array}{r}\text { Total GDP multiplier } \\
\text { change }\end{array}$ \\
\hline & percent \\
Agriculture & -5.2 \\
Forestry & -4.4 \\
Fishing & -3.8 \\
Primary support & -3.7 \\
Mining & -7.5 \\
Utilities & -6.6 \\
Construction & -3.9 \\
Manufacturing & -4.9 \\
Wholesale trade & -4.2 \\
Retail trade & -3.7 \\
Transportation & -4.0 \\
Information & -5.1 \\
Finance, insurance, real estate and rental and leasing & -4.9 \\
Professional and technical & -3.4 \\
Administrative & -3.6 \\
Education & -2.9 \\
Health care & -3.1 \\
Recreation & -3.9 \\
Accommodation and food & -3.8 \\
Other services & -3.7 \\
Non-profit institutions & -2.9 \\
Government & -3.3 \\
\hline Source: Statistics Canada, aus &
\end{tabular}

Source: Statistics Canada, authors' calculations.

While it is debatable whether a decline of $3 \%$ to $5 \%$ is significant, the negative effect of the financial crisis on the total GDP multipliers associated with an increase in investment funds for financial and non-financial corporations leaves no doubt of the seriousness of financial crisis. Chart 2 shows that the total GDP multipliers for each of the endogenous sectors declined. The decline in the total GDP multiplier given an increase in investment funds for households was similar in magnitude to the decline in the industry multipliers, but the decline for financial and non-financial corporations was much larger, at 30\% and 55\%, respectively.

The decline in the multipliers was driven primarily by two factors. First, during the first half of 2009, institutions, in particular financial corporations, invested a greater fraction of their financial assets in instruments assumed to be exogenous, namely government bonds, short-term government paper, and foreign investments. As a fraction of their total financial investment, investment in foreign and government-issued assets by financial corporations rose to $33 \%$ in the first half of 2009, 24 percentage points of which were due to government bonds (Chart 3). Although an all-time high was not reached in the first half of 2009 , the $33 \%$ contrasts sharply with the $7 \%$ exhibited in 2008. Second, a rising proportion of the liabilities were being taken out by government and financial corporations and a declining proportion taken out by non-financial institutions and households. Most importantly, the fraction of liabilities taken out by non-financial 
institutions fell below zero, while the fraction of liabilities taken out by government increased by 15 percentage points (Chart 4).

Compared to financial corporations, non-financial institutions and households devote a larger proportion of their investment funds to fixed assets, and it is this investment in fixed assets that directly contributes to increases in GDP. This tendency to invest more in fixed assets is reflected in the higher total GDP multipliers for households and non-financial corporations in Chart 2. In the case of rising government liabilities, because it is assumed that the government sector is exogenous, increases in government debt do not lead to more government spending. In reality, this may not be the case, as the elevated government debt levels might be used to finance investments in infrastructure or higher spending on social programs during an economic downturn.

\section{Conclusions}

In this paper, we construct an SAM for Canada for 2004 to assess the strength of the realfinancial linkages in the Canadian economy. We do this by comparing revenue and GDP multipliers with and without financial flows. We find that taking into account financial flows increases the impact of a final demand shock on Canadian output by 4\%. GDP multipliers give a more accurate estimate of the total impact on Canadian output of a final demand shock. The reason is that GDP multipliers, as opposed to revenue multipliers, net out second-round effects, that is, purchases that industries subsequently make from each other as a result of a change in final demand. This result is in line with DSGE models which show that the presence of the financial accelerator can amplify and propagate the effects of a demand shock to investment and has an effect on output fluctuations. ${ }^{12}$

Financial flows play an important role in determining the effect of a shock to income or funds for investment. The size of the effect depends on the portfolio decisions of financial institutions. Between 2008 and the first half of 2009, financial institutions shifted their investments towards government bonds, short-term paper, and foreign investments. The shift towards foreign and government assets, together with the fact that non-financial institutions were unwilling or unable to increase their financial liabilities, led to estimated declines in all GDP multipliers between 2008 and $2009 \mathrm{H} 1$. The impact of a final demand shock on GDP declined $3 \%$ to $5 \%$, while the impact of an increase in the availability of investment funds fell $30 \%$ and $55 \%$ for financial and non-financial corporations, respectively.

Multipliers of the type that we consider allow them only to determine the effects of exogenous shocks to final demand, income, or investment funds. Supply-driven multipliers (or Ghosh multipliers), in contrast, allow to determine changes in industry outputs resulting from exogenous changes in industry inputs of primary factors (labour, capital, and all other valueadded inputs). We leave this type of analysis to future work.

One important use of the SAM for Canada would be to calibrate a general equilibrium model based on SAM data for the most recently available year. We leave this application to future work.

\footnotetext{
${ }^{12}$ For example, Christensen and Dib (2008) estimate a DSGE model with a financial accelerator à la Bernanke et al (1999).
} 


\section{Appendices - A. Proof of proposition 1}

By definition, the Leontief inverse of the FSAM matrix must satify

This gives

$$
\left(\begin{array}{ll}
F_{11} & F_{12} \\
F_{21} & F_{22}
\end{array}\right)\left(\begin{array}{cc}
I-A^{S A M} & -A_{12} \\
-A_{21} & I
\end{array}\right)=\left(\begin{array}{cc}
I & 0 \\
0 & I
\end{array}\right) \text {. }
$$

$$
\begin{gathered}
F_{11}\left(I-A^{S A M}\right)-F_{12} A_{21}=I, \\
-F_{11} A_{12}+F_{12}=0, \\
F_{21}\left(I-A^{S A M}\right)-F_{22} A_{21}=0, \\
-F_{21} A_{12}+F_{22}=I .
\end{gathered}
$$

From (A.3), we get $F_{12}=F_{11} A_{12}$, i.e., (13), which, substituted into (A.2), gives

$$
F_{11}\left(I-A^{S A M}\right)-F_{11} A_{12} A_{21}=I .
$$

Factoring out $F_{11}\left(I-A^{S A M}\right)$, gives

$$
F_{11}\left(I-A^{S A M}\right)\left[I-\left(I-A^{S A M}\right)^{-1} A_{12} A_{21}\right]=I
$$

which, in turn, gives (11). (13) is obtained from (A.4). Substituting (13) into (A.4) gives

$$
-F_{21} A_{21}\left(I-A^{S A M}\right)^{-1} A_{12}+F_{22}=I,
$$

which, in turn, gives

$$
F_{22}\left[I-A_{21}\left(I-A^{S A M}\right)^{-1} A_{12}\right]=I .
$$

The last expression gives (12). 
Chart 1

Total GDP multiplier for manufacturing, 1961 to first half of 2009

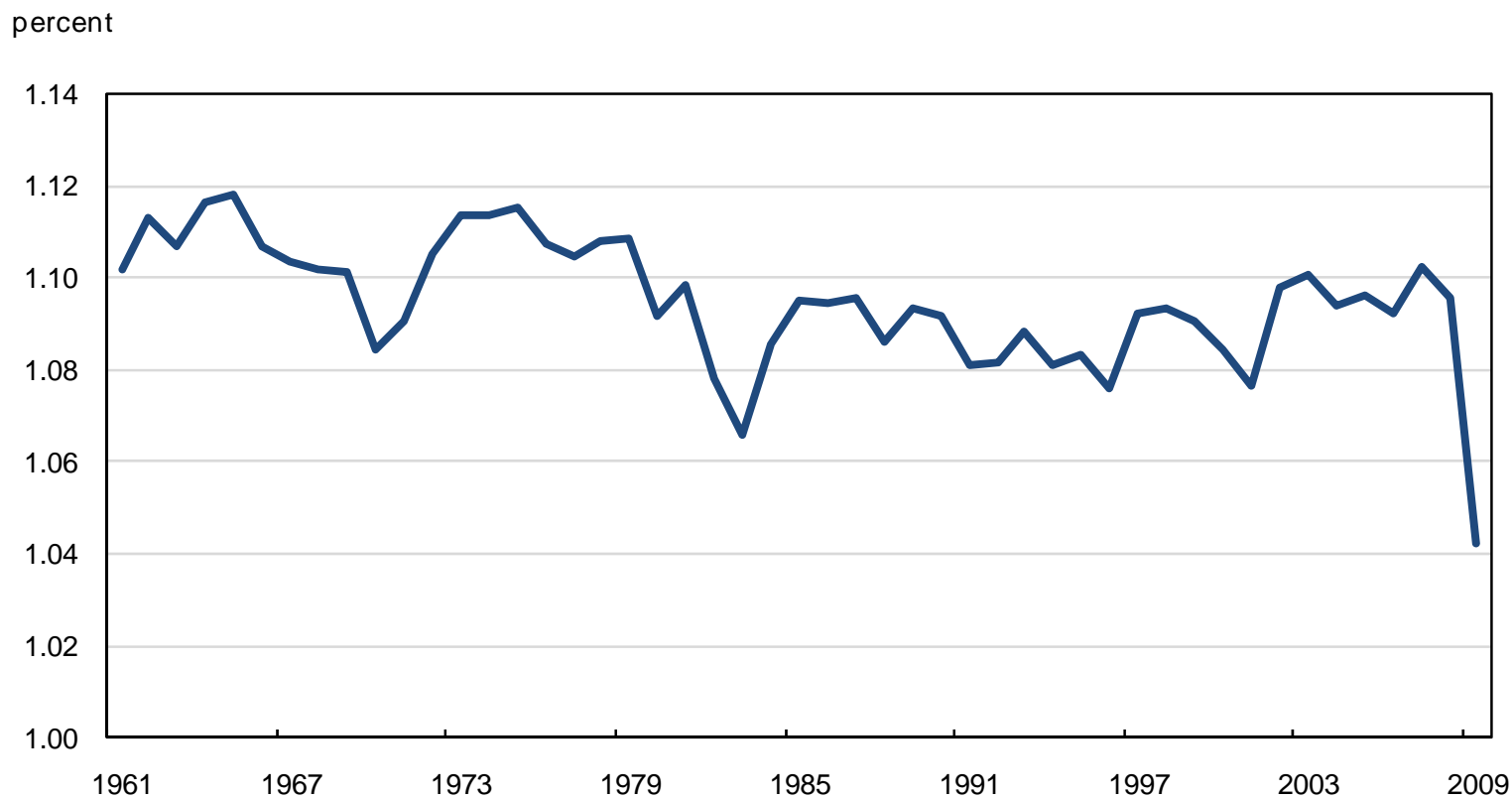

Chart 2

Total GDP multipliers associated with an increase in investment funds by institution, 1961 to first half of 2009

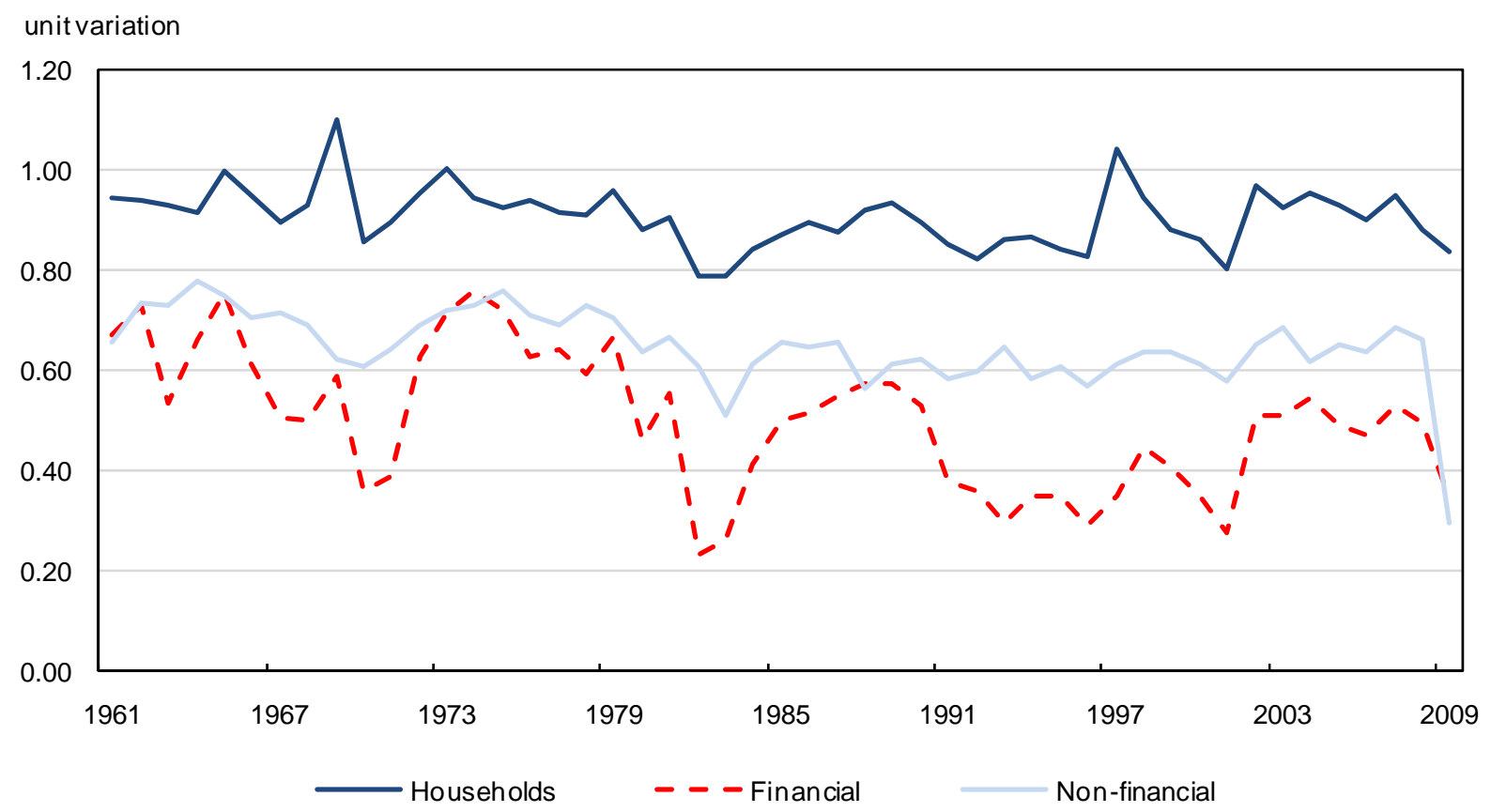




\section{Chart 3}

Financial investment in government and foreign assets as a percentage of total financial investment, financial corporations, 1961 to first half of 2009

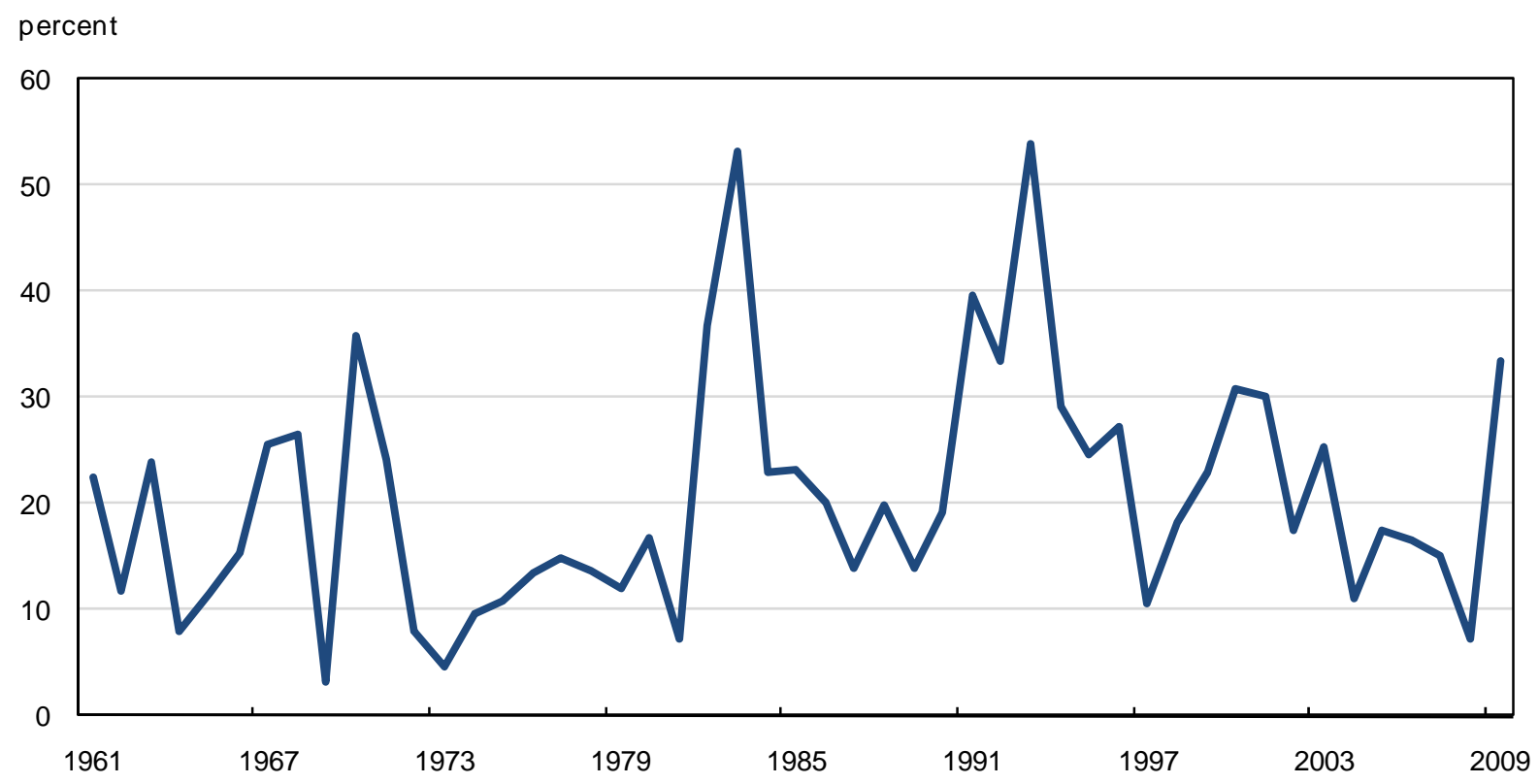

\section{Chart 4}

Shares of the change in financial liabilities by institution, 1961 to first half of 2009

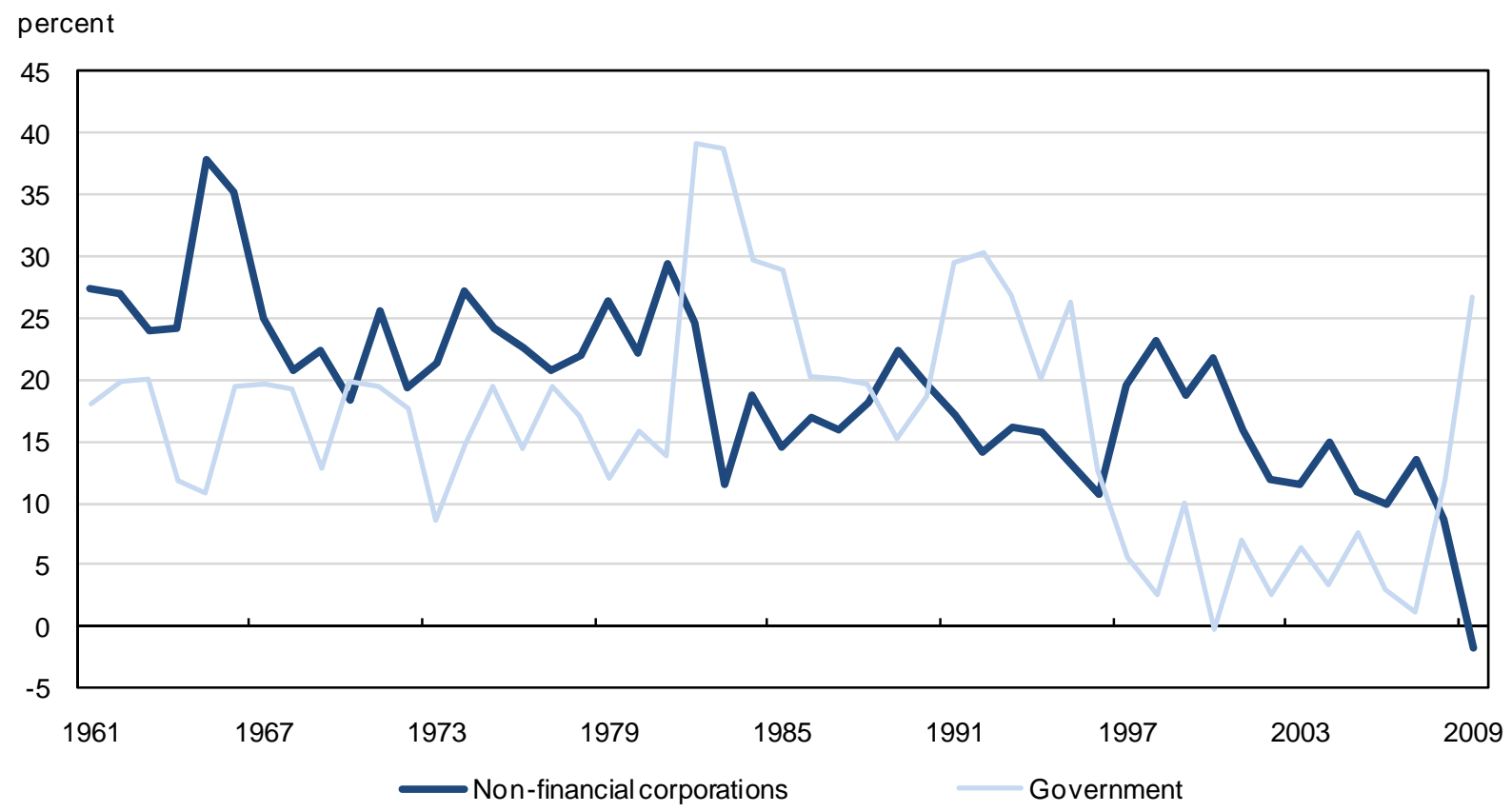




\section{References}

Bernanke, B., Gertler, M., Gilchrist, S., 1999. The financial accelerator in a quantitative business cycle framework. In: Handbook of Macroeconomics. North-Holland, Amsterdam.

Christensen, I., and A. Dib. 2008. "The Financial Accelerator in an Estimated New Keynesian Model." Review of Economic Dynamics. Vol. 11. No. 1. p. 155-178.

Cross, P., and Z. Ghanem. 2006. "Multipliers and Outsourcing: How industries interact with each other and affect GDP." Canadian Economic Observer. Statistics Canada Catalogue no. 11-010-XIB. Vol. 19. No. 1. Ottawa.

Dion, R., K. Flood, P. Hebert, E. Morin, and L. Morel. 2009. The North American Motor Vehicle Industry at a Crossroads. Bank of Canada: manuscript.

Ghanem, Z. 2005. The Canadian and Inter-Provincial Input-Output Models: The Mathematical Framework. Industry Canada. Ottawa

Li, J. 2008. The Financial Social Accounting Matrix for China, 2002, and its Application to a Multiplier Analysis. Forum of International Development Studies No. 36. p. 215-239. http://mpra.ub.uni-muenchen.de/8174/1/MPRA_paper_8174.pdf (accessed June 8, 2010)

Miller, R.E., and P.D. Blair. 2009. Input-Output Analysis: Foundations and Extensions. Cambridge University Press. Cambridge, England.

Rispoli, L. 2009. Trends in Gross Domestic Product and Self-employment of Unincorporated Enterprises in the Canadian Economy, 1987 to 2005. Insights on the Canadian Economy Analytical Paper. Statistics Canada Catalogue no. 11-624-M. No. 24. Ottawa.

Siddiqi, Y., and M. Salem. 2006. A Social Accounting Matrix for Canada. Paper prepared for the $29^{\text {th }}$ General Conference of the International Association for Research in Income and Wealth. August 20 to 26, 2006. Joensuu, Finland. http://www.iariw.org/papers/2006/salem.pdf (accessed June 8,2010 )

Sonis, M., and G.J.D. Hewings. 1999. "Miyazawa's contributions to understanding economic structure: interpretation, evaluation and extensions." Understanding and Interpreting Economic Structure. G.J.D. Hewings, M. Sonis, M. Madden, and Y. Kimura (eds.). Advances in Spatial Sciences. Heidelberg, Germany. Springer-Verlag.

ten Raa, T. 2005. The Economics of Input-Output Analysis. Cambridge University Press. Cambridge, England.

Thorbecke, E., and H.-S. Jung. 1996. "A Multiplier Decomposition Method to Analyze Poverty Alleviation." Journal of Development Economics. Vol. 48. No. 2. p. 279-300.

Timmer, M., and P. Aulin-Ahmavaara. 2007. "New Developments in Productivity Analysis within an Input-Output Framework: an Introduction." Economic Systems Research. Vol. 19. No. 3. p. 225-227.

Wixted, B., N. Yamano, and C. Webb. 2006. Input-Output Analysis in an Increasingly Globalised World: Applications of OECD's Harmonised International Tables. OECD Science, Technology 
and Industry Working Papers. No. 2006/7. Directorate for Science, Technology and Industry, OECD. Paris. 